\title{
Introduction and use of non-native species for aquaculture in China: status, risks and management solutions
}

\author{
Yaping Lin ${ }^{1,2}$, Zexia Gao ${ }^{3}$ and Aibin Zhan ${ }^{1}$ \\ 1 Research Center for Eco-Environmental Sciences, Chinese Academy of Sciences, Beijing, China \\ 2 University of Chinese Academy of Sciences, Beijing, China \\ 3 College of Fisheries, Key Laboratory of Agricultural Animal Genetics, Breeding and Reproduction of Ministry of Education/Key Laboratory of \\ Freshwater Animal Breeding, Ministry of Agriculture, Huazhong Agricultural University, Wuhan, China
}

\section{Correspondence}

Prof. Aibin Zhan, Research Center for Eco-Environmental Sciences, Chinese Academy of Sciences, 18 Shuangqing Road, Haidian District, Beijing 100085, China. Email: zhanaibin@hotmail.com

Received 21 January 2013; accepted 19 October 2013.

\begin{abstract}
Aquaculture is one of the fast-growing industries in the past decades. The fast expansion of aquaculture largely relies on the introduction and use of non-native species. This forms a paradox: some species significantly contribute to the fast expansion of aquaculture, while negative effects associated with unregulated introduction and irresponsible use of non-native species are increasing in number and area affected. However, lessons from reported disasters are slowly learned, and risks raised have been highly overlooked. Here, we discuss the known and potential risks derived from the introduction and use of non-native species in China to urge the necessity of incorporating sound management into sustainable aquaculture. Sound management needs to be performed based on the characteristics of each aquaculture activity or related event. We discuss risks based on aquaculture activities or related events popularly employed in the past decades in China, including (i) transfers of non-native species; (ii) fellow travellers, accidental introductions; (iii) artificial hybridization; and (iv) mass release of non-native species for ranching. For each aquaculture activity or related event, we provide general background, status of this activity, risks raised and recommendations for management. Finally, we call for the collaboration of researchers from academia, government and aquaculture industry for proper risk assessment and sound management for sustainable development of aquaculture.
\end{abstract}

Key words: aquaculture, invasive species, non-native species, risk assessment, sustainable development.

\section{Introduction}

Aquaculture is the fast-growing section of world primary industry in the past decades (Food \& Agriculture Organization of the United Nations (FAO) 2012). In 2010, global aquaculture production reached more than 83 million tons and a value of US\$ 136 million, which are six and ten times more than those 25 years ago (Fig. 1). Now, aquaculture supplies almost half of aquatic food consumed worldwide (FAO 2012). As demands for aquatic food are quickly increasing in global markets, aquaculture is expected to further expand in many countries, including both developing and developed countries (FAO 2012).

Among many factors responsible for fast expansion of aquaculture, the introduction and use of non-native species plays one of the most crucial roles (e.g. Shelton \& Rothbard
2006; De Silva et al. 2009). However, accelerating introduction and/or use of non-native species have formed a paradox. There is little doubt that, like introduced crops and live-stock for agriculture, the introduction of aquatic species is a valid means to improve aquaculture production (Bartley et al. 2005; Gozlan 2008). For example, non-native finfish species contribute to approximately $17 \%$ of the world's production (FAO 2012). Some countries rely on farming of non-native aquatic species, for example, $60 \%$ of the freshwater harvest in the Philippines and 50\% of the production in Brazil is derived from non-native species (Shelton \& Rothbard 2006). However, unregulated introduction and irresponsible use of non-native species lead to severe risks and threats to local environments, economies and human activities (e.g. De Silva 2012). Owing to a huge contribution to economic growth, food supply and 
Figure 1 Global and China aquaculture production in both quantity (ton) and value (US\$) in each year. Data from FAO at http://www. fao.org/fishery/statistics/global-aquacultureproduction/en.

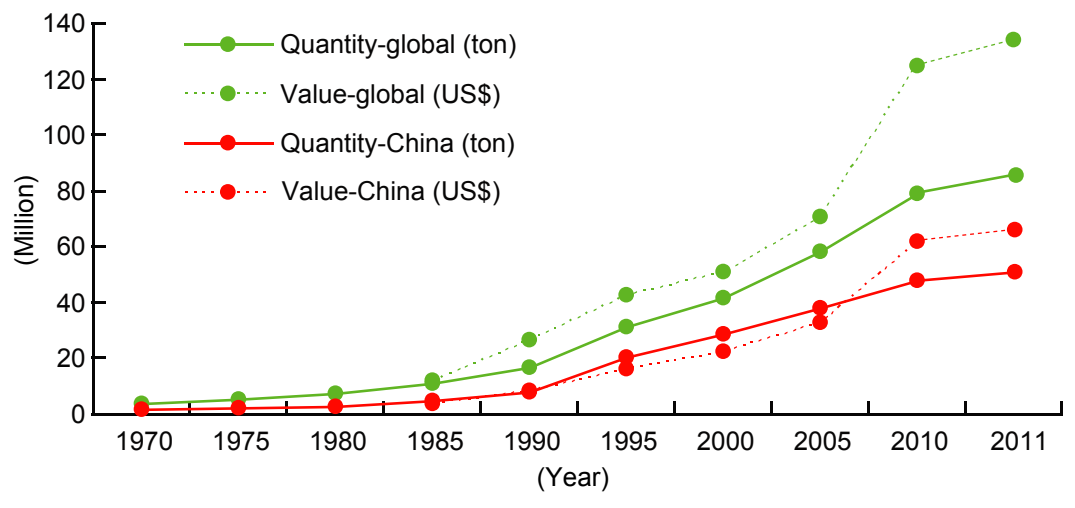

introduction and/or use of highly valued non-native species. Negative effects may appear suddenly or gradually as the time since establishment of non-native species is extended (Jeschke \& Strayer 2005). However, lessons from known disasters are slowly learned (see known disasters in each section). Moreover, some risks and negative effects have been realized, but many remain unknown or overlooked. It is therefore necessary to perform comprehensive risk assessment on species that are proposed for introduction. In addition, research progress on management of harmful species has accumulated in the past two decades (e.g. Lodge et al. 2006; Messing \& Wright 2006).

Based on such progress, we propose recommendations for the sound management of introduced non-native species for sustainable aquaculture. Sound management needs to be performed based on the characteristics of each aquaculture activity, such as scale, potential adverse effects and risks associated with each activity. Here, we discuss risks based on aquaculture activities popularly employed in the past several decades. We focus on high-risk activities and related events in this review. For each activity, we provide basic background, status of this activity in China, risks associated with this activity, and recommendations for management.

\section{Transfers of non-native species}

\section{Background}

Aquaculture has become one key driver for the deliberate introduction of non-native species (Naylor et al. 2001; Peeler et al. 2011). So far, a total of 5612 records of species introduction have been collected by FAO (Database on Introductions of Aquatic Species, http:// www.fao.org/fishery/dias/en). Given the fact of unavailability of data in some countries, especially developing countries in Asia where aquaculture expands fast, the number of introduction events is likely larger. The underestimated number can also be seen from the statistics performed by FAO: $76 \%$ of introduced species are made by unknown groups (Fig. 2). 


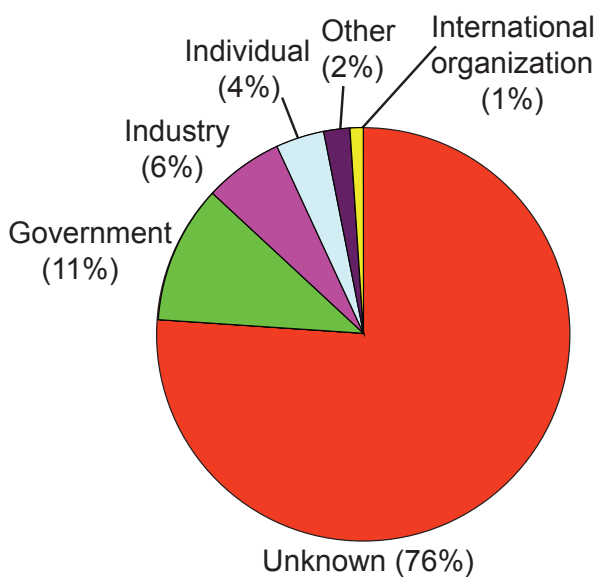

Figure 2 Organizations responsible for the total of 5612 records for the introduction of aquatic species for aquaculture. Data from Database on Introductions of Aquatic Species (DIAS) at FAO website (http://www. fao.org/fishery/introsp/search/en).

Much attention has been paid to the international introduction of non-native species. The domestic transfer of species to locations where they do not naturally occur has been highly overlooked. Despite efforts made to minimize adverse effects, a well-recognized view of degree of risks and approaches to risk assessment have not been achieved in many countries, even those categorized as vulnerable ones to establishment of non-native species (Doupé \& Lymbery 2000). Indeed, the domestic transfer is widely employed in geographically large countries such as China, where valued aquaculture species are usually restricted to limited geographical regions. The scale of domestic transfer, including the number of individuals, geographical sale involved and frequency of transfer, is much larger than that of international transfer, especially for commercial aquaculture purposes (e.g. Liu 2005; Shelton \& Rothbard 2006). Despite the fact that the transfer of non-native species has gained attention from scientific communities (e.g. Naylor et al. 2001; De Silva et al. 2006, 2009; Laikre et al. 2010; De Silva 2012), many local and/or national governments have not regulated or not strictly regulated aquaculture-related introductions, especially for domestic transfers.

\section{Species introductions in China}

The introduction and use of non-native species for aquaculture in China started as early as 1920s (Fig. 3). A total of 179 species (virus and bacteria excluded) were internationally introduced into China for aquaculture or due to aquaculture-related activities (Table 1; Fig. 4a). These species include desired aquaculture species, accidental species transferred along with desired species (i.e. fellow travellers), and those introduced via other vectors but used as aquaculture species after introductions (Table 1). Due to difficulties to track origins and poor historical records of micro-organisms such as virus, bacteria and other pathogens, we excluded this group in this review. Among these 179 species, the top four taxonomic groups are fish (111 species), molluscs (27 species), algae (16 species), and crustaceans (14), accounting for $93.9 \%$ of all introductions (Fig. 4a). Among these four groups, fish and molluscs are the most diverse, covering ten orders and eight infraorders/ families/superfamilies respectively (Fig. 4a). For introduced fish, the major group is Perciformes (39 species), accounting for $35.1 \%$, while the most abundant groups of introduced molluscs are Haliotidae (7 species) and Pectinoida (7 species), accounting for $51.9 \%$ of the total (Fig. $4 a$ ).

The number of species introduced before 1970 was small, totally 13 in this half century (1920-1969). Frequent introductions began from 1970s as the total aquaculture production started to sharply increase. More than 150 species were introduced in the past forty years, with an average 3.8 species per year (Fig. 3). The largest number was detected in 1990s, with a total of 56 species introduced. These introduced species contribute to the fast expansion of aquaculture in China. A large proportion of these introduced species $(52.5 \%)$ has been successfully cultured (Table 1 ), and these non-native species have contributed to aquaculture production in China ( $>25 \%$ of total production; Shelton \& Rothbard 2006). Two well-known examples are the introductions of the Pacific white shrimp Penaeus vannamei and red swamp crayfish Procambarus clarkii. The total production of the Pacific white shrimp doubled in both marine and freshwater aquaculture in the past 10 years, from 308947 ton in 2003 to 665588 ton in 2011 (marine) and from 296312 ton in 2003 to 659961 ton (freshwater), accounting for $74.3 \%$ (marine) and $43.6 \%$ (freshwater) of the total production of category 'shrimp, prawn, crayfish and lobster' (Fig. 5). Although negative effects of the red swamp crayfish were well recognized and emphasized in both scientific literature and public media in the beginning of 2000s (e.g. Wang 2003), aquaculture still expands and production keeps increasing, reaching 563281 ton in 2010, more than ten times than that in 2003 (Fig. 5). Now, the production of this crayfish accounts for more than $30 \%$ of the total production of the category 'shrimp, prawn, crayfish and lobster' (Fig. 5).

For domestic transfers, almost all provinces in China, including inland and coastal ones, have introduced species for aquaculture. A total of 73 species (virus and bacteria excluded) have clear records of transfer beyond their native ranges (Table 2; Fig. 4b). Among these 73 species, the most abundant group is fish (61 species), accounting for $83.6 \%$ of all introduced species (Fig. 4b). The introduced fish cover 12 orders, of which Cypriniformes is the largest (25 species, Fig. 4b). Although 12 
Figure 3 Number of non-native species introduced into China due to aquaculture or related activities (bar chart and left $x$-axis), and total aquaculture production in China in the past 90 years (dotted line and right $x$-axis).
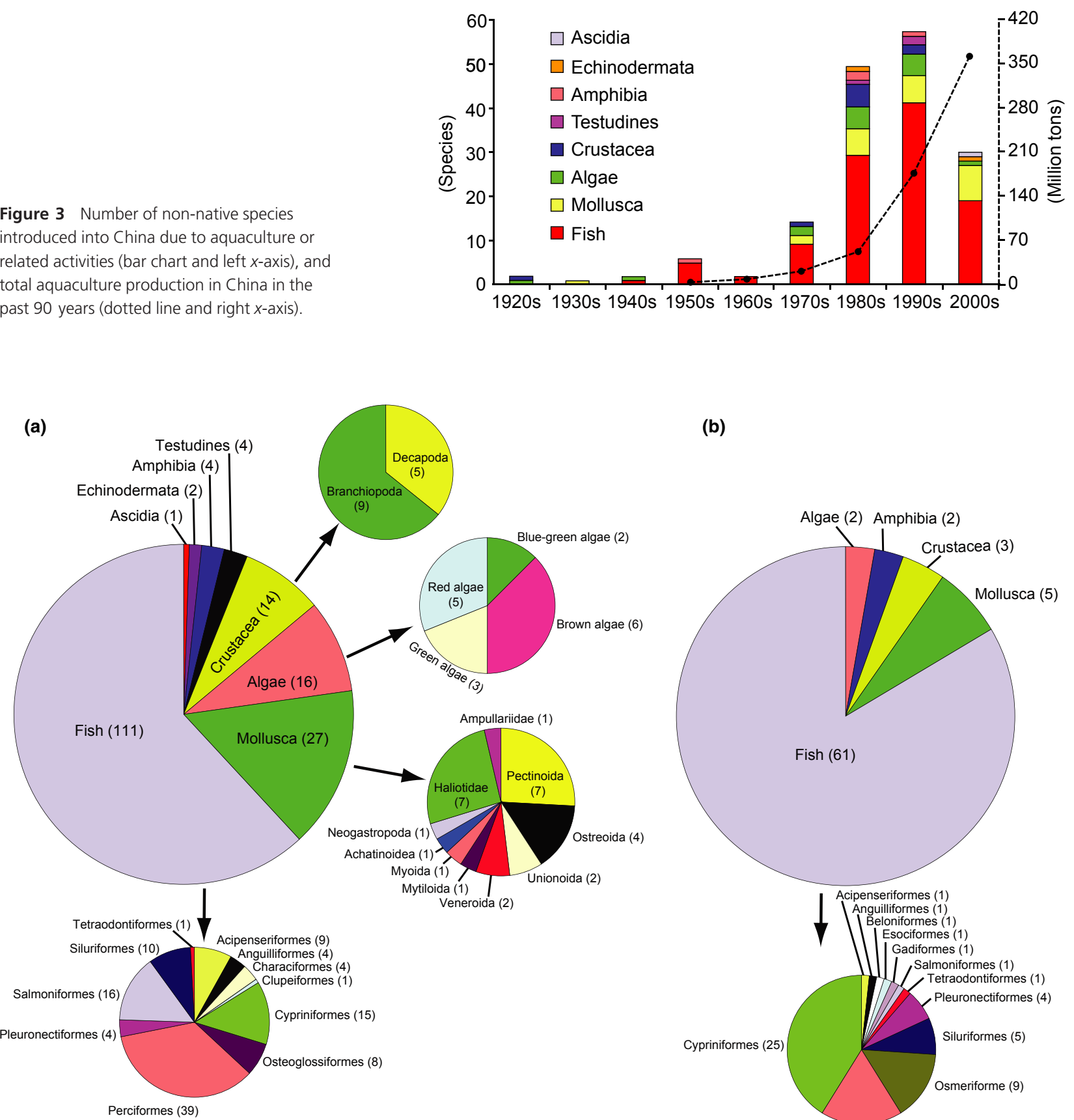

(b)

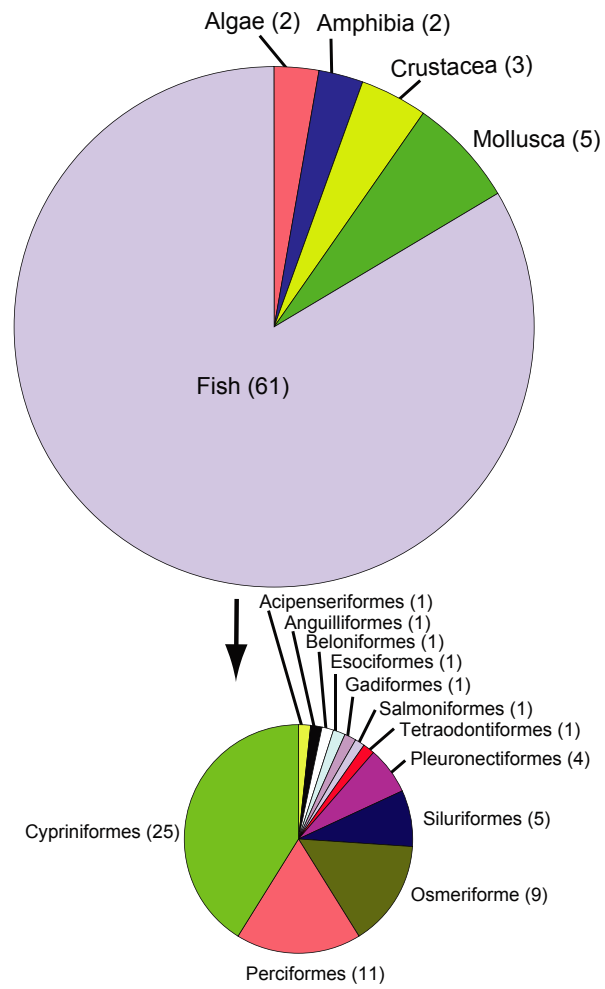

Figure 4 Taxonomic composition of non-native species internationally introduced into China (a) and domestically transferred within China (b) due to aquaculture or related activities. The number of species in each taxon is shown in brackets after taxon name.

species are detected to have negative effects/history of biological invasions, they have been transferred and employed for aquaculture (Table 2).

For domestic transfers, both the number of individuals and total value of transferred species are extremely large. For example, only in Hongdao, a coastal town in Qingdao city, Shandong Province, the total value of introduced seed of Ruditapes philippinarum and Sinonovacula constrictais is more than 100 million Chinese Yuan (more than US\$ 16 million) per annum (Liu 2005; Liu et al. 2007a). For the fresh water system, lakes in Yunnan Province represent well-known examples. Starting in 1958, the four major Chinese carps (black carp Mylopharyngodon piceus, grass carp Ctenopharyngodon idellus, silver carp Hypophthalmich- 


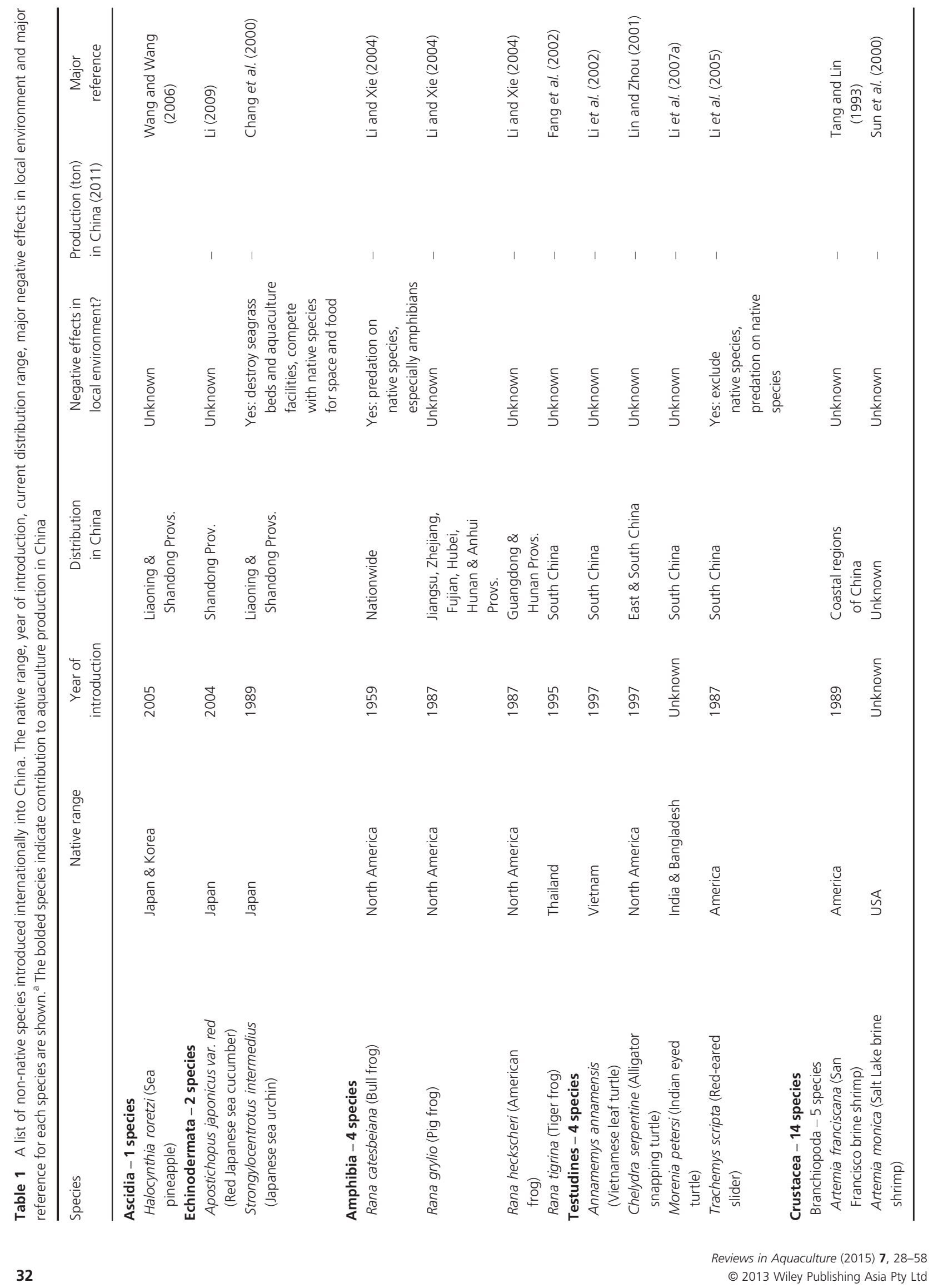




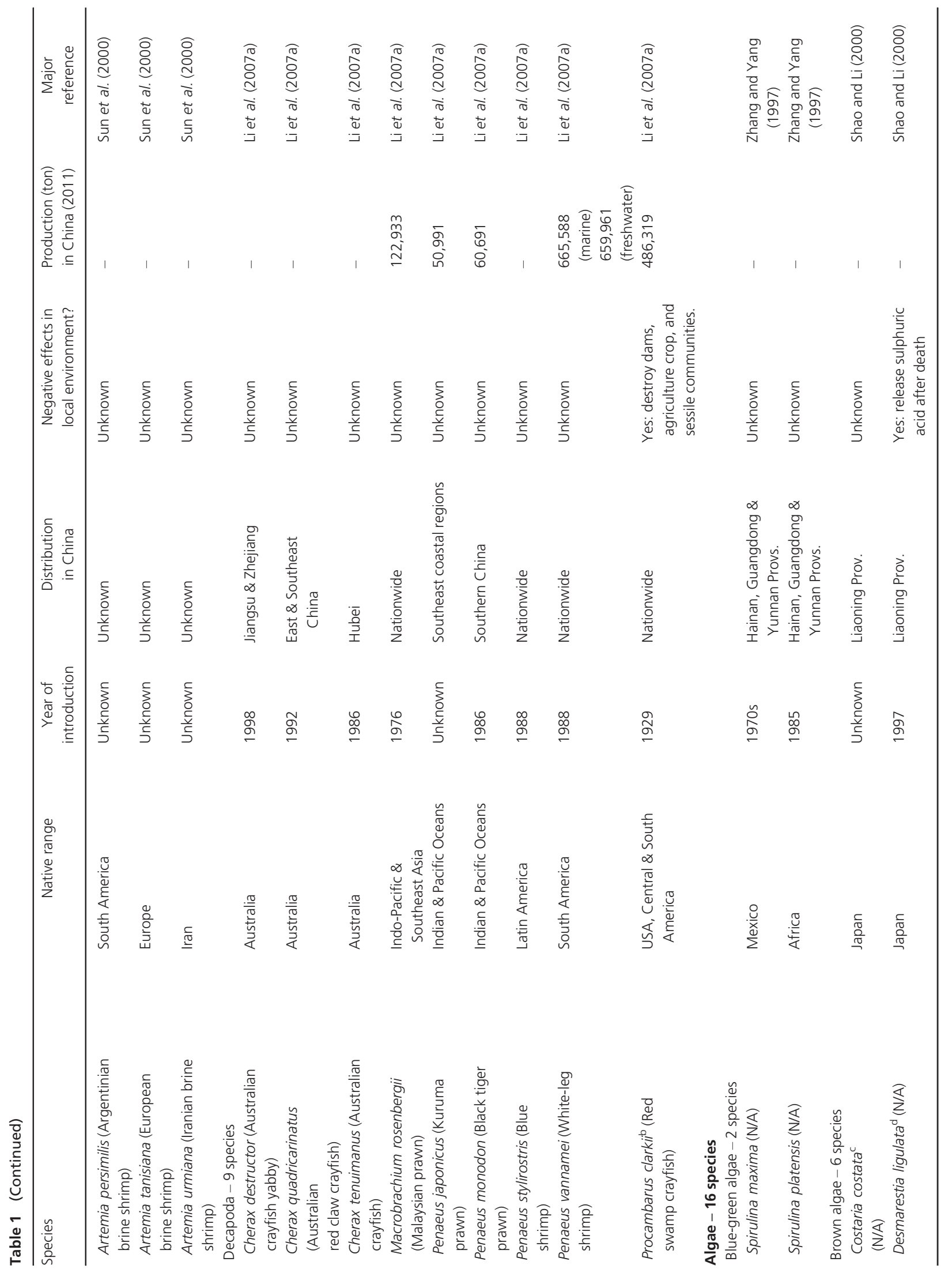




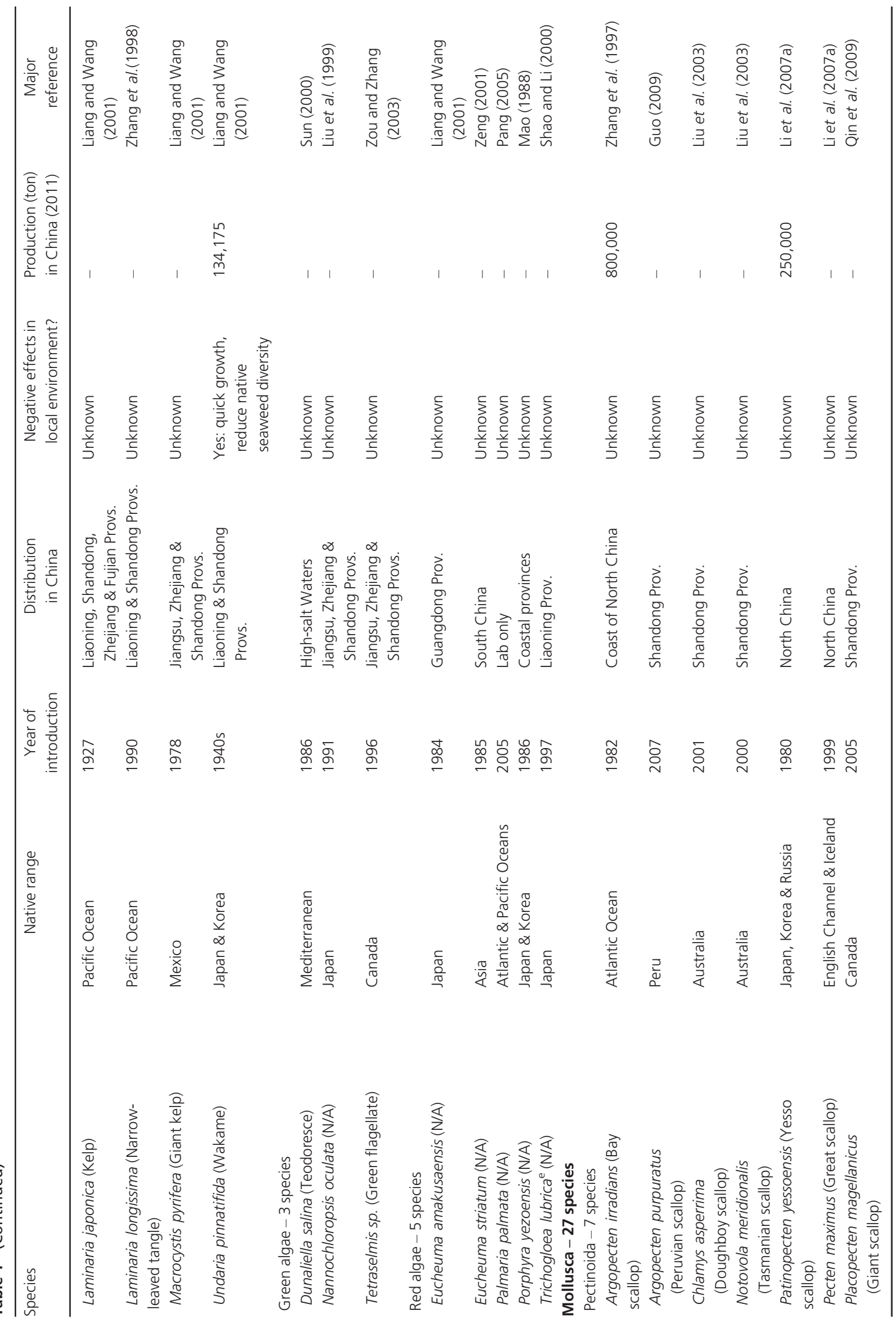




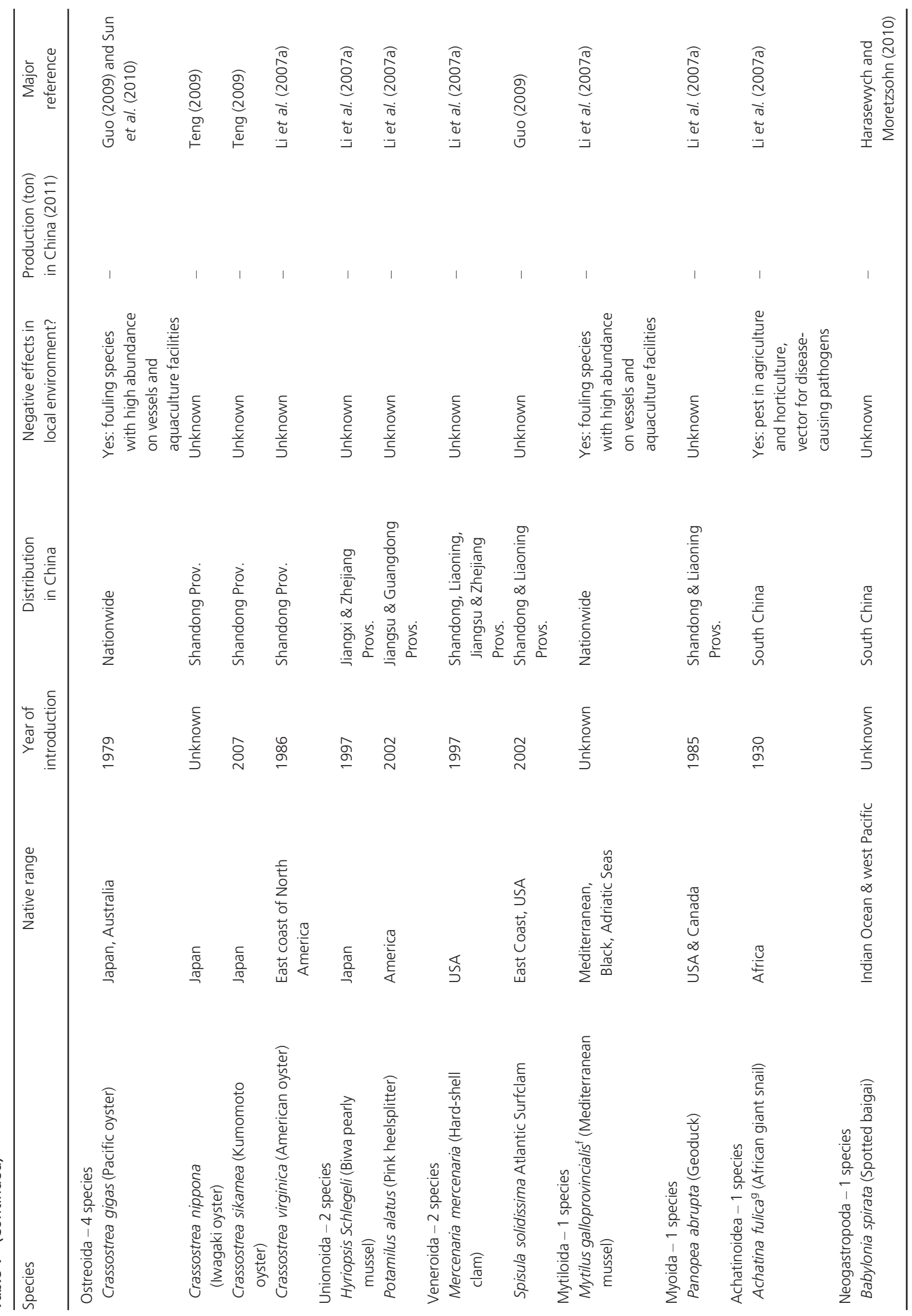




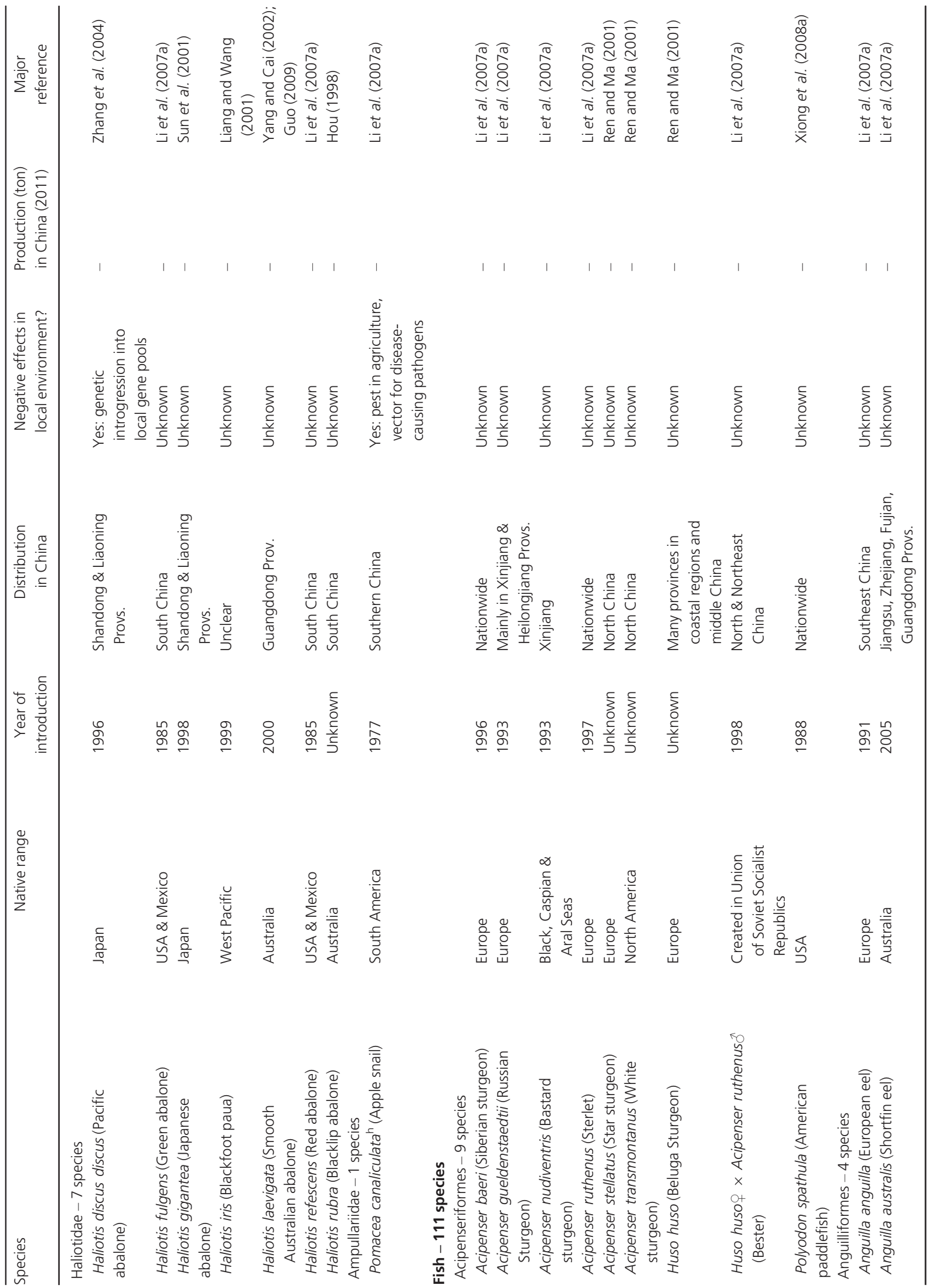




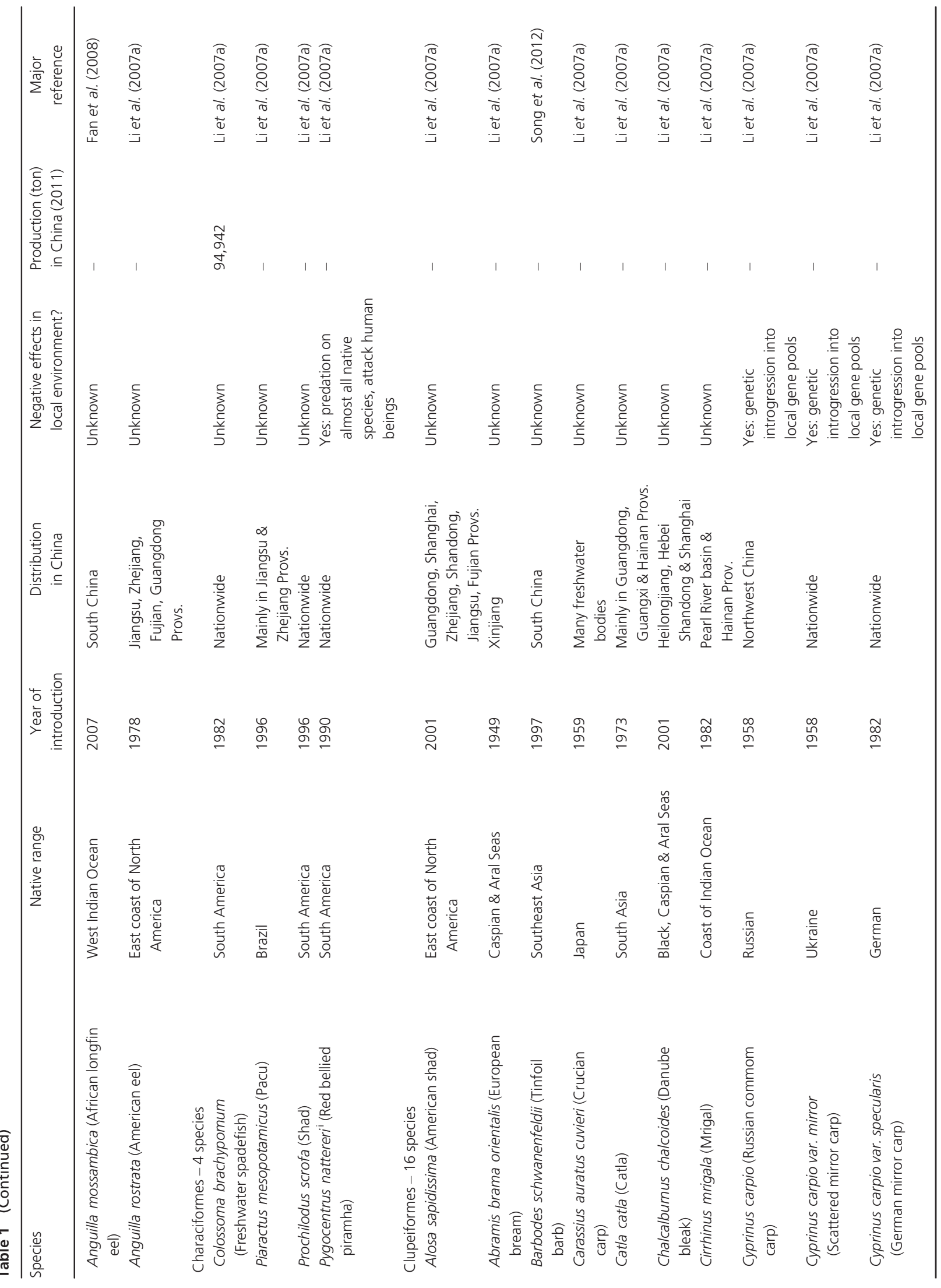




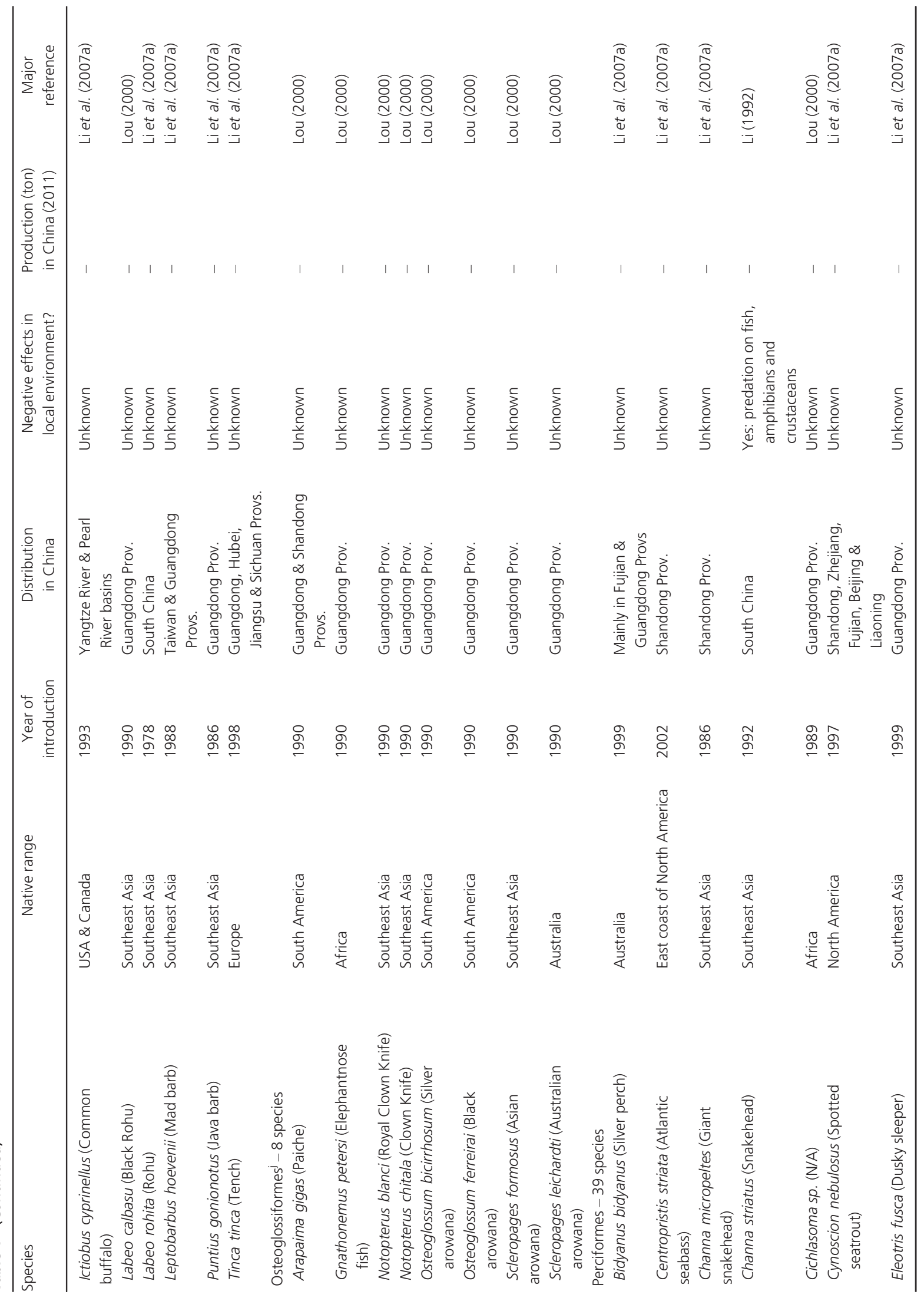




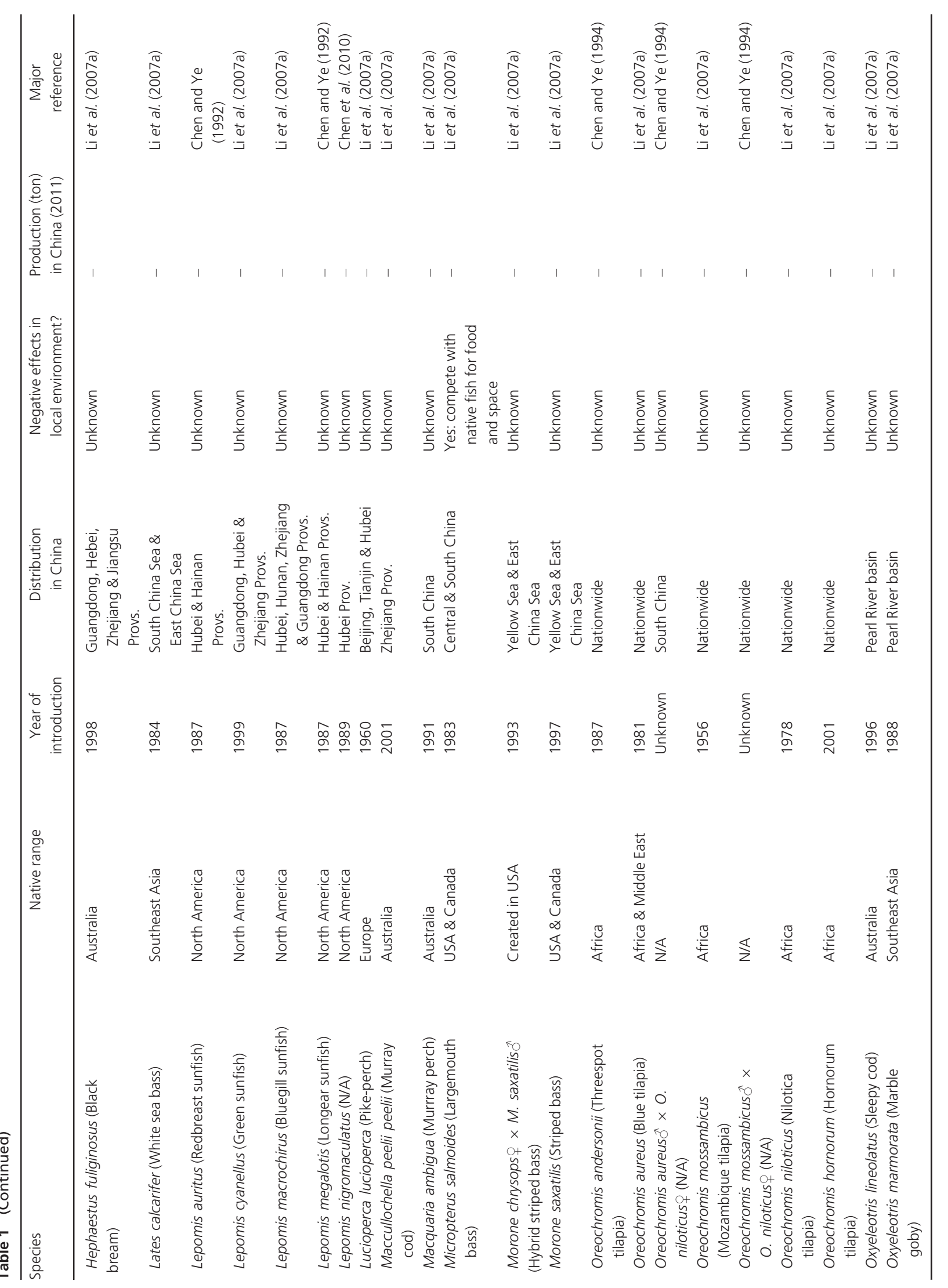




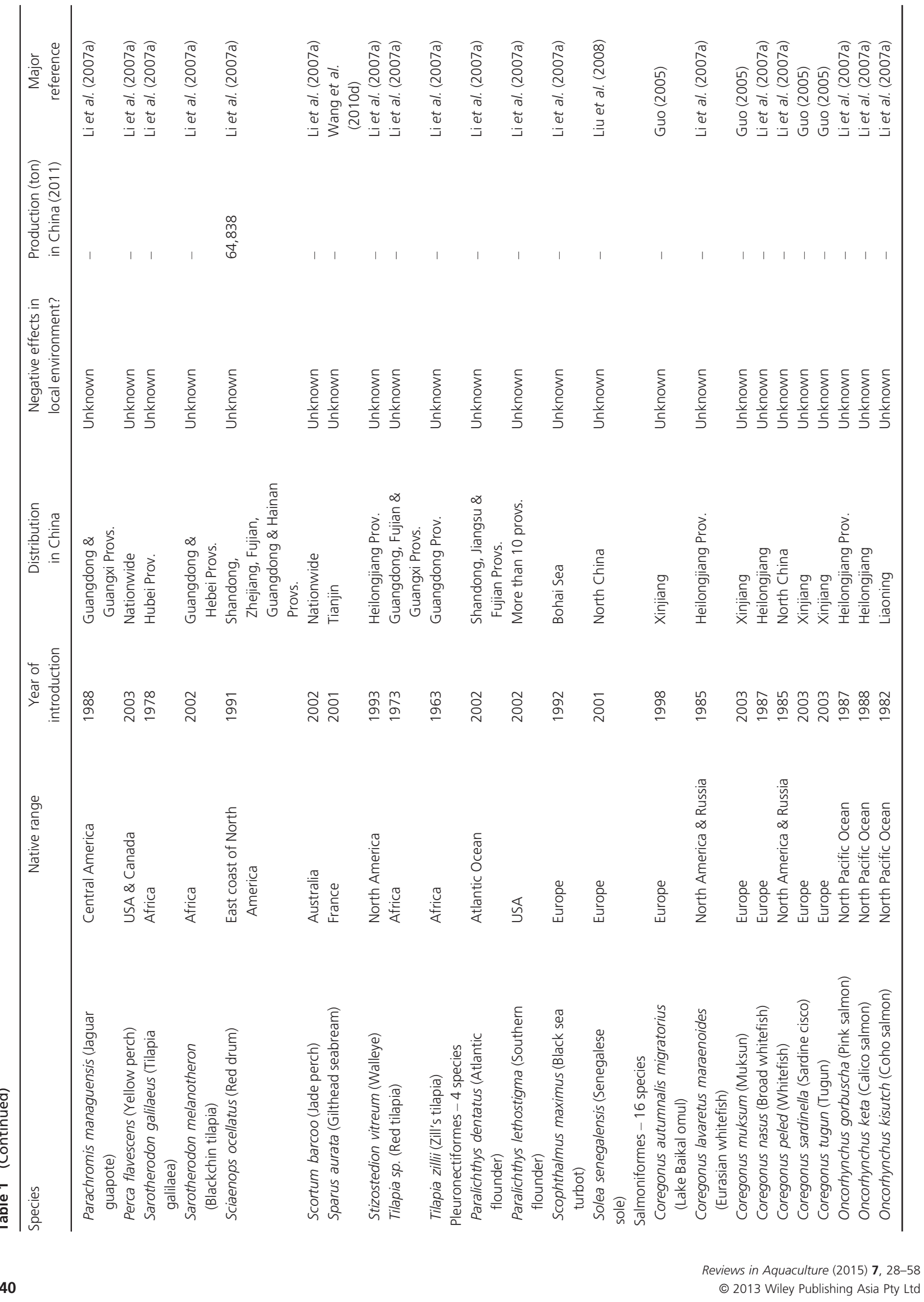




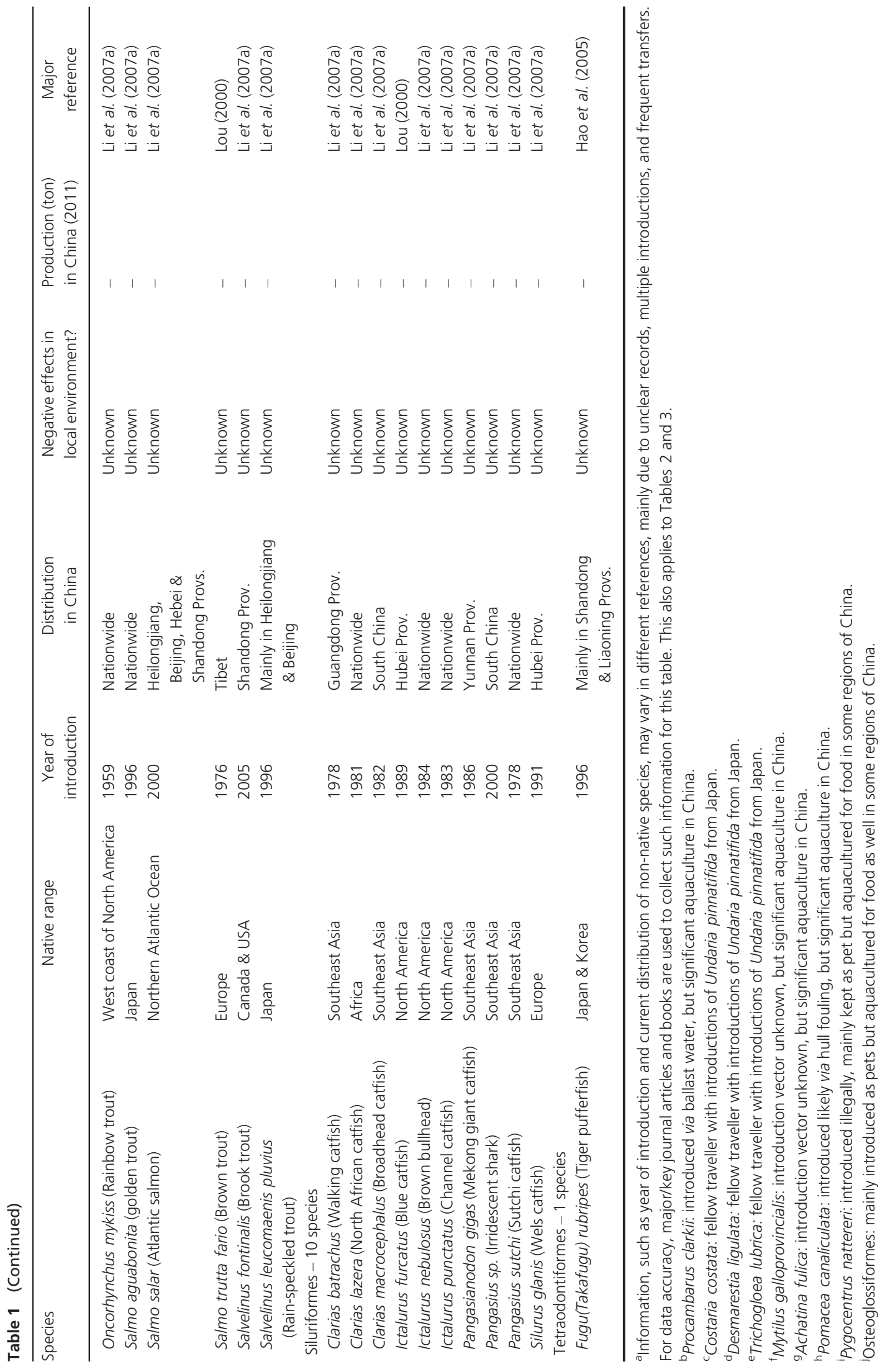




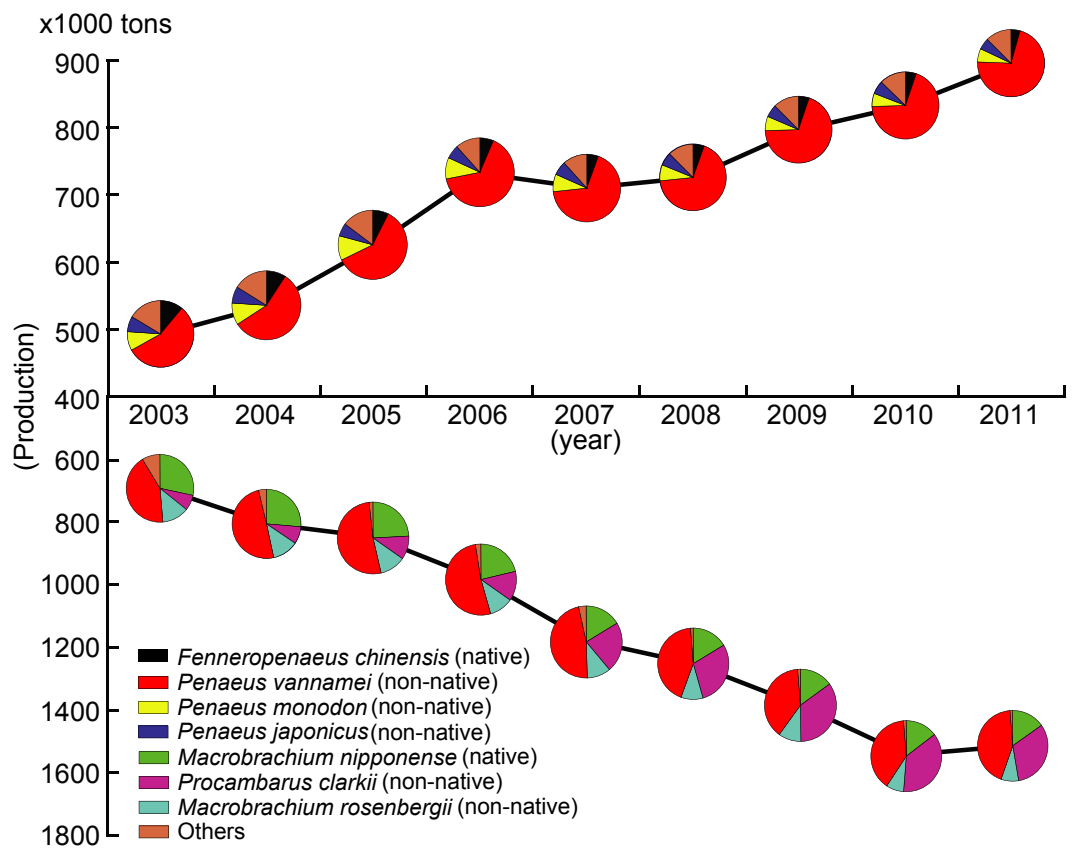

Figure 5 Aquaculture production in the category of 'shrimp, prawn, crayfish and lobster' from 2003 to 2011 (line graph), and production proportion of each major species in each year (pie chart) in China. Data from China Fisheries Yearbook (2004-2012). thys molitrix, bighead carp Aristichthys nobilis) were introduced into major lakes in Yunnan Province. The introduction and release scale are extremely large, for example, the total number of released individuals of these four carp species reaches more than four million per annum in Lake Dian (Chen et al. 1998).

\section{Risks}

Established species may spread widely and become invasive at new locations (i.e. biological invasions), sometimes after a lag phase of many years in which populations remained small and localized (O'Dowd et al. 2003; Jeschke \& Strayer 2005). Among 179 species introduced internationally into China, 17 (9.5\%) have had negative effects on local environments (Table 1 and references therein). These negative effects include ecosystem degradation (e.g. sea grass beds destroyed by the Japanese sea urchin Strongylocentrotus intermedius, Liu et al. 2007a), loss of biodiversity and even species extinction (e.g. devastating predation on native amphibians by the bull frog Rana catesbeiana, Li \& Xie 2004), and faunal homogenization (e.g. the red-bellied piramha Pygocentrus nattereri become dominant in many water bodies by excluding/killing/eating almost all native species, Li et al. 2007a). Moreover, some invasive species are associated with economic impacts, including increased operating costs (e.g. fouling by the Pacific oyster Crassostrea gigas, Sun et al. 2010) and lost revenue (e.g. agriculture crops destroyed by the apple snail Pomacea canaliculata, Li et al. 2007a). Although other species have not had detectable negative effects, risks may still remain due to a lag phase of biological invasions.

When compared with the international transfer of nonnative species, domestic translocation may possess even higher risks, mainly owing to easy transfer, time- and cost saving, a large number of propagules involved, and importantly lack of restriction regulations. The introduction of fish from the Yangtze River drainage into major lakes in Yunnan Province plays one of the most important roles for the loss of biodiversity. Yunnan Province is a hotspot of biodiversity for freshwater fish in China, with more than 430 endemic species in this province (Chen et al. 1998). Lake Dian, which is the biggest lake in Yunnan Province, had 23 native species based on historical records, 11 of which are endemic to this lake. After the introduction of fish from the Yangtze River drainage, especially the four major Chinese carps, the number of native species decreases extremely fast: from 23 to 15 in 1978, to eight in 1982, to two in 1997, and only one in 2007-2008, and all endemic species become extinct (Chen et al. 1998; Yuan et al. 2010). By contrast, both the number of non-native species and population size sharply increase. For example, $93.8 \%$ of species is non-native in Lake Dian in the survey conducted in 2007-2008 (Fig. 6). This decrease in native species and increase in non-native species also happened in other major lakes in Yunnan province. For example, the production of fish in Lake Erhai increased from less than 2500 ton in 2001 to more than 5000 ton in 2009, and all major captured fish were non-native (Fei et al. 2011). All endemic species in 7 of 9 lakes surveyed are extinct, and the 


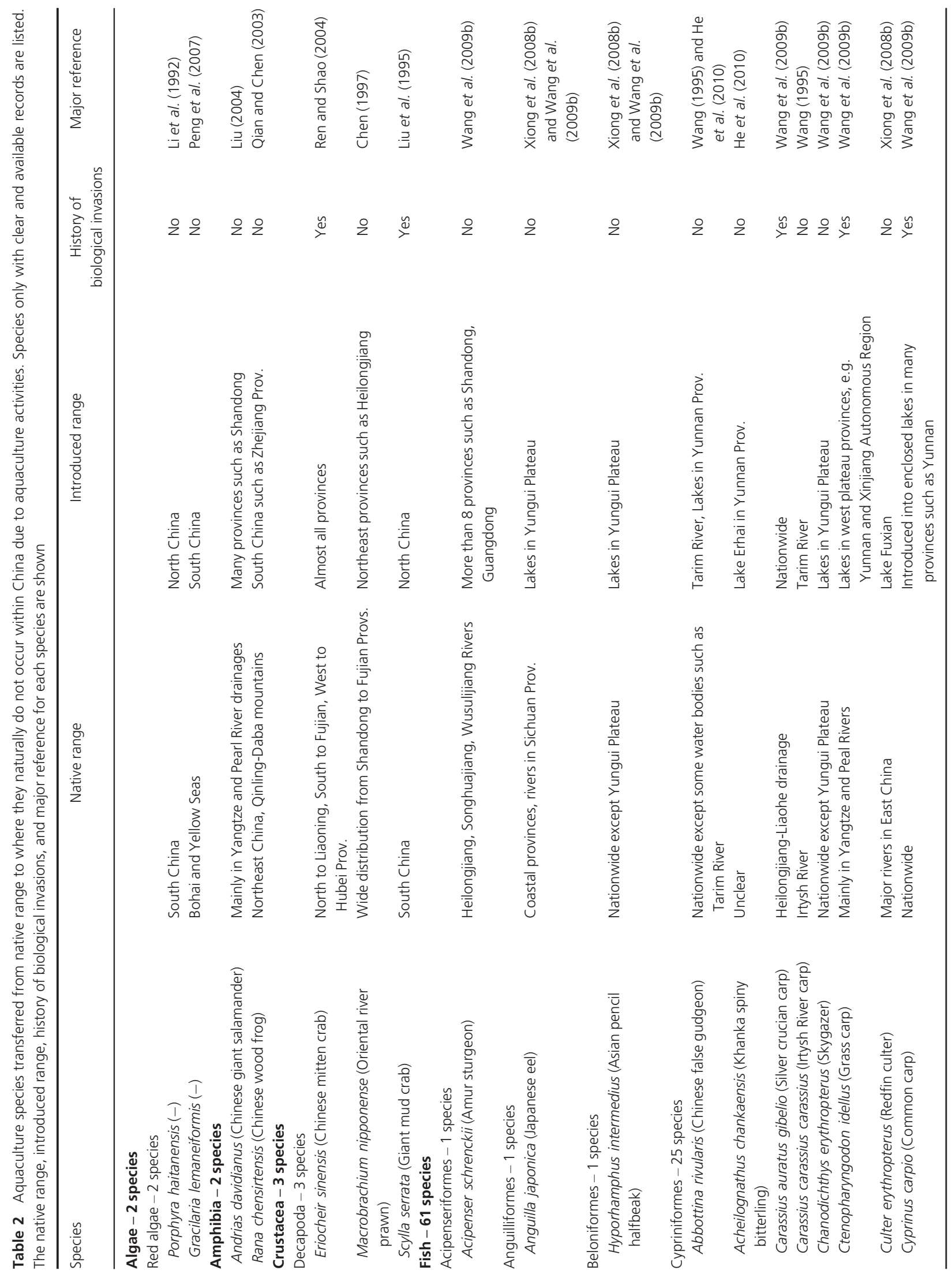




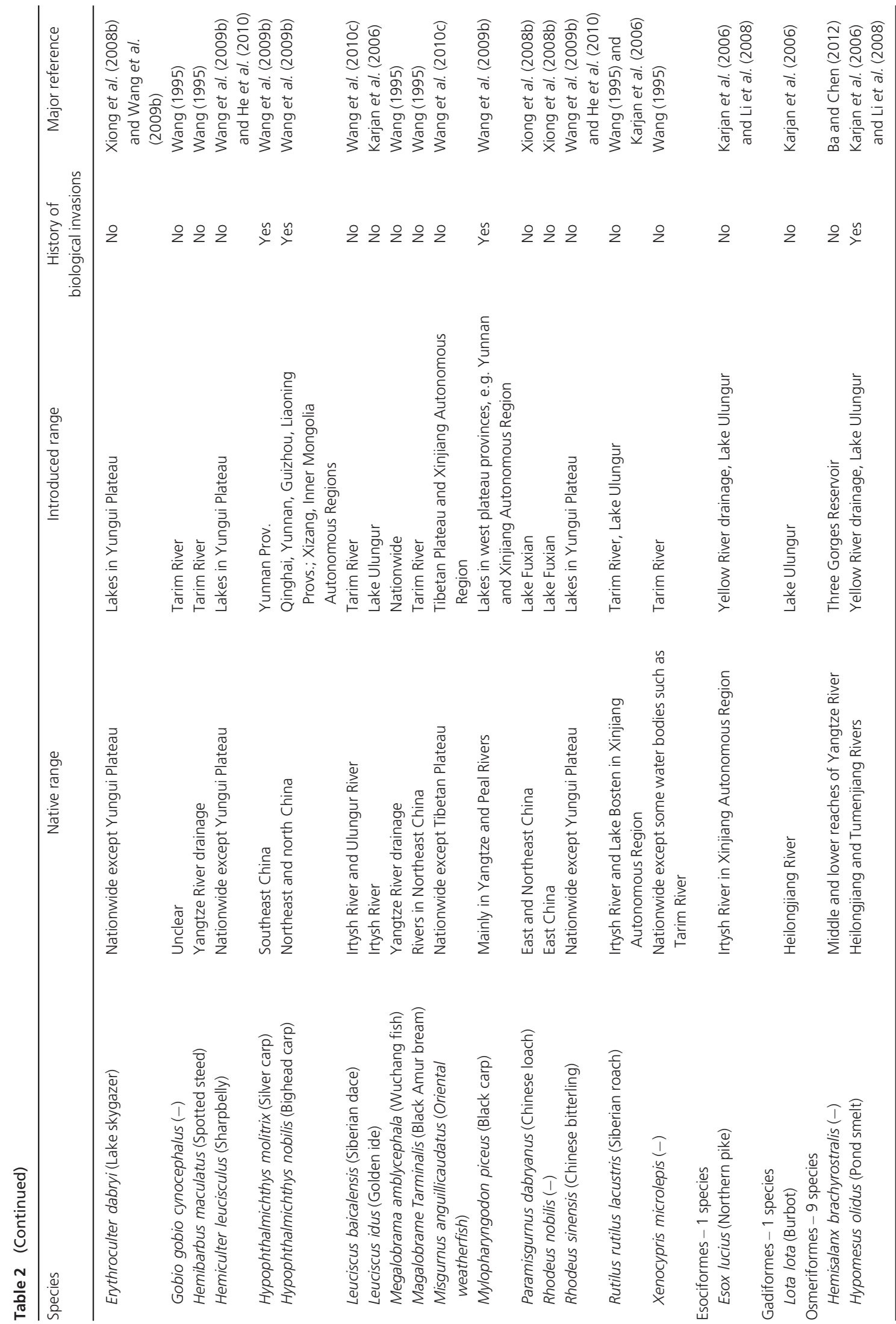




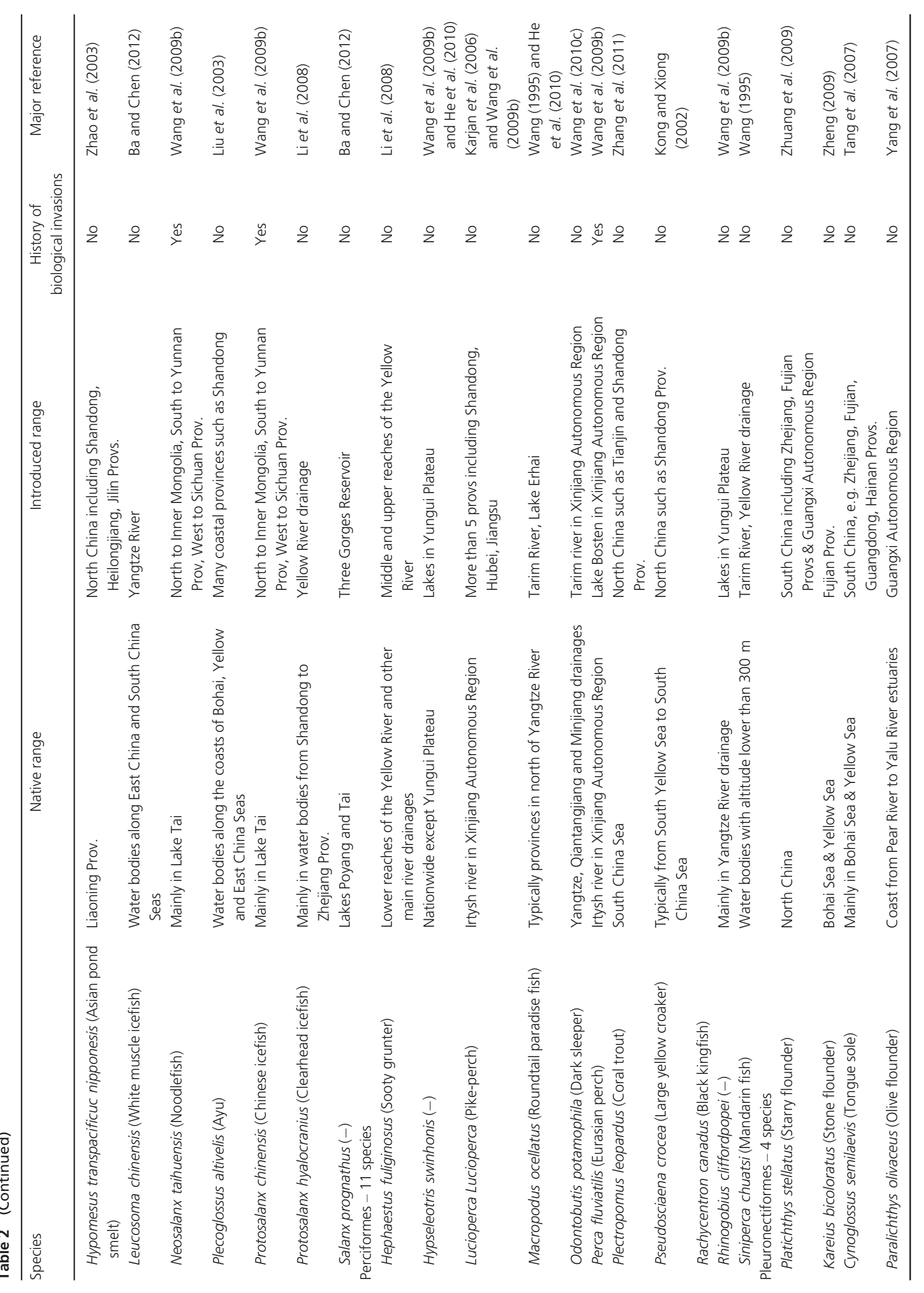




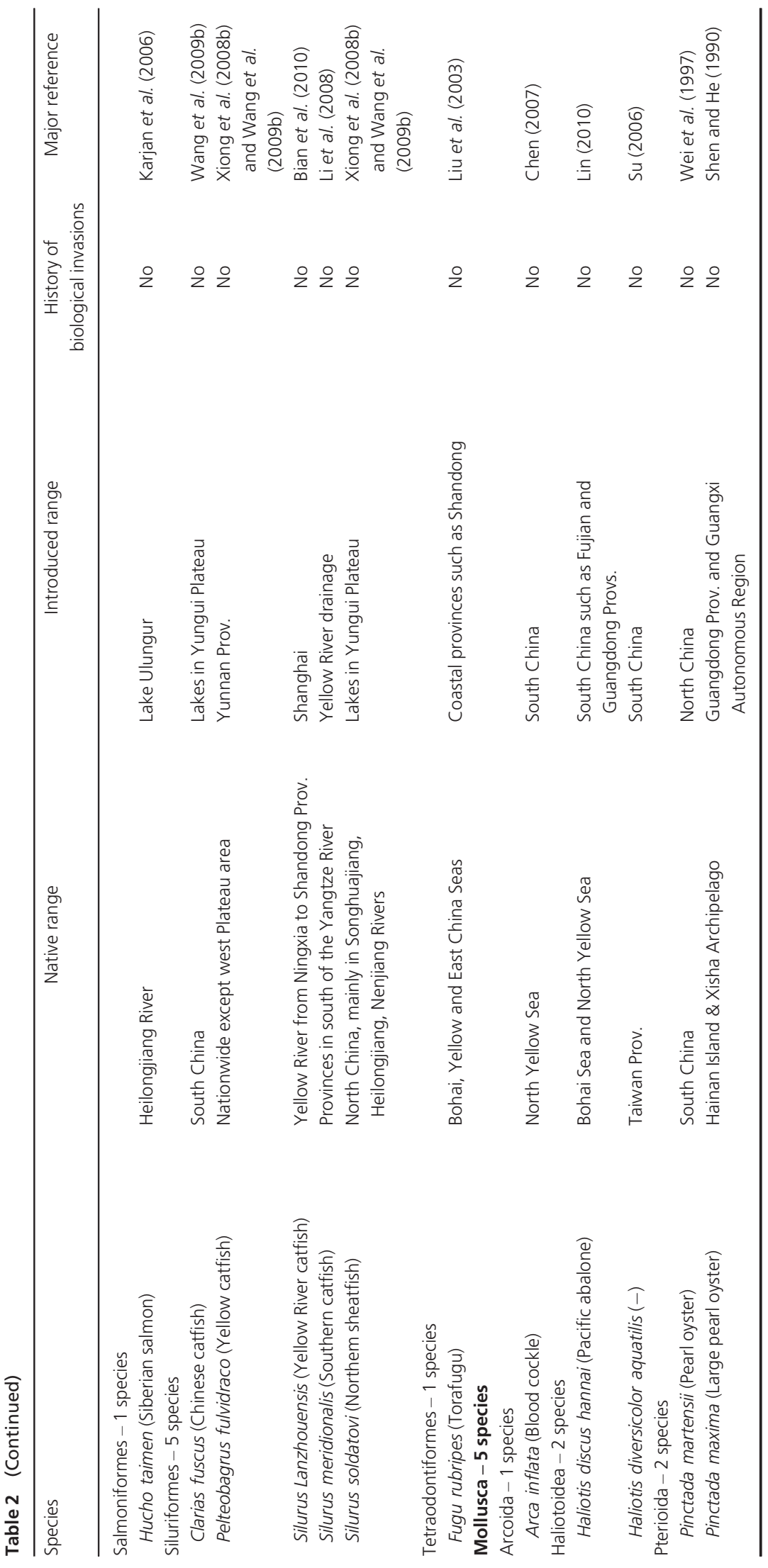


Table 3 Successful inter-specific hybridization with non-native species involved in China. Names of non-native species are bolded. 'Adult hybrids successfully obtained' is used as an indicator of 'successful hybridization'

\begin{tabular}{|c|c|c|}
\hline Taxonomic group & Hybridization setup & Major reference \\
\hline Echinoderms & Strongylocentrotus intermedius (†) $\times$ S. nudus (ठ) & Wang et al. (2003) \\
\hline \multirow[t]{14}{*}{ Molluscs } & Argopecten purpuratus $(+) \times A$. irradians $\left({ }^{\lambda}\right)$ & Wang et al. (2009a) \\
\hline & Argopecten irradians $(\varphi) \times A$. purpuratus $(\hat{)})$ & Zhang et al. (2012a) \\
\hline & Haliotis discus hannai $($ (†) $\times$ H. gigantea $(\widehat{)})$ & Wang (2006) \\
\hline & Haliotis gigantea $($ () $) \times H$. discus $(ふ)$ & Wang (2006) \\
\hline & Haliotis discus hannai $($ () $) \times$ Haliotis discus discus $(\widehat{ })$ & Wan et al. (2001) \\
\hline & Haliotis discus discus $(0) \times$ Haliotis discus hannai $\left({ }^{(}\right)$ & Wan et al. (2001) \\
\hline & Haliotis fulgens $(\uparrow) \times$ Haliotis discus hannai $(\widehat{\jmath})$ & Fan (2012) \\
\hline & Haliotis discus hannai $\left(\right.$ (†) $\times$ × Haliotis fulgens $\left({ }^{\circledR}\right)$ & Fan (2012) \\
\hline & Haliotis refescens $(\uparrow) \times$ Haliotis discus hannai $\left({ }^{\circledR}\right)$ & Wang and Fan (1999) \\
\hline & Haliotis discus hannai $(\uparrow) \times$ Haliotis refescens $\left({ }^{\prime}\right)$ & Wang and Fan (1999) \\
\hline & 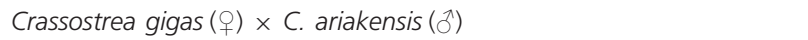 & Zhang et al. (2012b) \\
\hline & Crassostrea ariakensis $($ ( $) \times$ C. gigas $\left({ }^{\lambda}\right)$ & Zhang et al. (2012b) \\
\hline & Crassostrea sikamea $(0+) \times C$. gigas $\left({ }^{\circledR}\right)$ & Teng (2009) \\
\hline & Crassostrea gigas $\left(\right.$ (†) $\times$ C. sikamea $\left({ }^{\Uparrow}\right)$ & Teng (2009) \\
\hline \multirow[t]{2}{*}{ Algae } & Laminaria longissima $(\stackrel{+}{)}) \times$ L. japonica $\left({ }^{\jmath}\right)$ & Li et al. (2007b) \\
\hline & 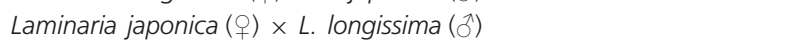 & Zhang et al. (2007) \\
\hline \multirow[t]{38}{*}{ Fish } & Acipenser schrencki $(+)) \times A$. ruthozus $\left({ }^{\lambda}\right)$ & Wang et al. (2010a) \\
\hline & Acipenser schrencki (†) $\times$ Huso huso (ठ) & Ren et al. (2012) \\
\hline & Huso dauricus $(+9) \times$ Acipenser baeri $\left(\delta^{\pi}\right)$ & Liu et al. (2007b) \\
\hline & Huso huso $($ ( $) \times$ Acipenser baeri $\left({ }^{\Uparrow}\right)$ & Gao et al. (2006) \\
\hline & Acipenser schrencki $($ $(+) \times A$. gueldenstaedti $(\precsim)$ & Sun et al. (2009) \\
\hline & Acipenser schrencki $($ ( $) \times($ Huso huso $\uparrow \times$ Acipenser ruthenus $\widehat{\jmath})(\widehat{)})$ & Sun et al. (2009) \\
\hline & Acipenser gueldenstaedti (ㅇ) $\times$ Huso dauricus (ð) & Hu et al. (2008) \\
\hline & Acipenser baeri $(\uparrow) \times$ Huso dauricus $(\hat{0})$ & Hu et al. (2008) \\
\hline & Acipenser ruthozus $(+)) \times$ Huso dauricus $\left({ }^{\Uparrow}\right)$ & Hu et al. (2008) \\
\hline & Acipenser gueldenstaedti $(+) \times A$. baeri $\left(\widehat{O}^{\prime}\right)$ & Hu et al. (2008) \\
\hline & Acipenser baeri $(\uparrow) \times A$. schrencki $(\widehat{0})$ & Wang et al. (2010b) \\
\hline & Acipenser ruthozus $(+) \times A$. schrencki $\left({ }^{\circledR}\right)$ & Wang et al. (2010b) \\
\hline & Acipenser schrencki $(\hat{+}) \times A$. baeri $(\hat{0})$ & Wang et al. (2010b) \\
\hline & Huso huso (†) $\times$ Acipenser ruthozus (ふึ) & Yang (2006) \\
\hline & Oxyeleotris marmorata $(+9) \times 0$. lineolatus $\left({ }^{(}\right)$ & Fan et al. (2009) \\
\hline & Oxyeleotris lineolatus (†) $\times$ O. marmorata $(ふ)$ & Fan et al. (2009) \\
\hline & Oreochromis niloticus $($ (†) $\times 0$. aureus $(\hat{\jmath})$ & Yang et al. (2006) \\
\hline & Oreochromis mossambicus $($ ( $) \times 0$. hornorum $(\widehat{\jmath})$ & Yang et al. (2006) \\
\hline & Oreochromis aureus $(+)) \times$ Sinipperca chuatai $\left({ }^{\Uparrow}\right)$ & Yu et al. (2003) \\
\hline & Oreochromis mossambicus $(+\circ) \times 0$. niloticus $\left.\left({ }^{(}\right)\right)$ & Liu et al. (1985) \\
\hline & Oreochromis aureus $($ ㅇ $) \times 0$. niloticus $\left(\partial^{\lambda}\right)$ & Xia et al. (1999) \\
\hline & Oreochromis niloticus (ㅇ) $\times$ Sarotherodon melanotheron (ふ̋) & Yan et al. (2007) \\
\hline & Sarotherodon melanotheron $($ () $) \times$ Oreochromis niloticus $(\precsim)$ & Yan et al. (2007) \\
\hline & Lepomis cyanellus $(+) \times$ Lepomis macrochirus $(\hat{)})$ & Chen and Su (2006) \\
\hline & Perca flavescens $(+)) \times P$. schrenki (ठ̂) & Ding et al. (2012) \\
\hline & Hephaestus fuliginosus $($ ( ) $) \times$ Scortum barcoo $\left({ }^{\Uparrow}\right)$ & Lu and Wang (2010) \\
\hline & Paralichthys olivaceus (ㅇ) $\times$ P. dentatus (ふ) & Guan et al. (2007) \\
\hline & Paralichthys lethostigma $\left(\right.$ (ㅇ) $\times$ P. dentatus $\left({ }^{\wedge}\right)$ & Gong (2009) \\
\hline & Fugu flavidus $(\uparrow) \times F$. rubripes $\left(ठ^{\circledR}\right)$ & Fan et al. (2011) \\
\hline & Oncorhynchus mykiss (†) $\times$ O.kisutch (ふ̋) & Xu et al. (2006) \\
\hline & Oncorhynchus mykiss (†) x Oncorhynchus masou masou (ふ̋) & Zhang et al. (2009) \\
\hline & Cyprinus carpio var. specularis (†) $\times$ Megalobrama amblycephala $\left({ }^{(}\right)$ & Jin et al. (2003) \\
\hline & 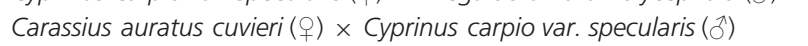 & He et al. (1995) \\
\hline & Carassius auratus cuvieri (ㅇ) $\times$ Cyprinus carpio var. singuonensis $\left({ }^{\prime}\right)$ & Chen (2000) \\
\hline & Carassius auratus auratus $(\phi) \times C$. auratus cuvieri $\left({ }^{\wedge}\right)$ & Lou et al. (1995) \\
\hline & Cyprinus carpio var. wananensis $($ ( $) \times C$. carpio var. specularis $\left({ }^{\jmath}\right)$ & Chi et al. (2010) \\
\hline & Cyprinus carpio var. specularis (ㅇ) $\times$ C. carpio var. wananensis (ठ) & Chi et al. (2010) \\
\hline & Cyprinus carpio var. mirror $($ ㅇ $) \times$ C. carpio var. specularis (ふ̋) & Liu et al. (1993) \\
\hline
\end{tabular}


Table 3 (Continued)

\begin{tabular}{|c|c|c|}
\hline Taxonomic group & Hybridization setup & Major reference \\
\hline & Cyprinus carpio haematopterus (ㅇ) $\times$ C. carpio var. mirror (ठ) & Ge et al. (2012) \\
\hline & Cyprinus carpio var. mirror $(+\circ) \times$ C. carpio haematopterus $(\widehat{\jmath})$ & Ge et al. (2012) \\
\hline & Cyprinus carpio var. singuonensis $($ ( $) \times C$. carpio var. mirror $\left({ }^{\Uparrow}\right)$ & Dong et al. (1999) \\
\hline & Cyprinus carpio var. mirror $(+\circ) \times C$. carpio var. singuonensis $\left({ }^{\Uparrow}\right)$ & Dong et al. (1999) \\
\hline & Clarias macrocephalus $(+9) \times$ C. fuscus $\left({ }^{\circledR}\right)$ & Wu et al. (1990) \\
\hline & Clarias fuscus $(+) \times$ C. lazera $(ふ)$ & Wu et al. (1990) \\
\hline & Clarias lazera $(0) \times C$. fuscus $\left({ }^{\natural}\right)$ & Zhang (1989) \\
\hline & Clarias macrocephalus (ㅇ) $\times$ C. lazera (ふへ) & Wu et al. (1990) \\
\hline
\end{tabular}

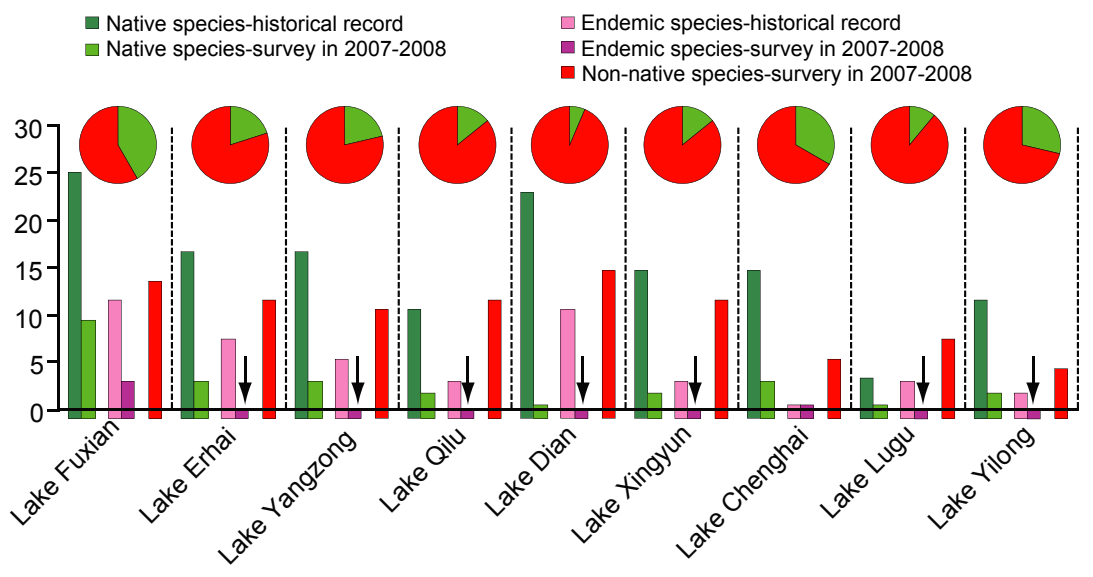

Figure 6 Number of species in different categories, including native, non-native and local endemic, in nine major lakes in Yunnan Province based on both historical records and survey conducted in 2007-2008 (bar chart), and proportion of native and non-native species in each lake in the survey of 2007-2008 (pie chart). Arrows indicate that all endemic species have been extinct based on the data from 2007-2008 survey. All data from Yuan et al. (2010).

majority of fish species in these lakes are non-native (Fig. 6). Although many factors, such as overfishing, reclamation of land from lakes, dam construction, pollution, and others may contribute to such loss of biodiversity (Chen et al. 1998), the fact is that both the number and production of non-native species increase. All evidence suggests that the introduction of non-native species plays a role for such loss of biodiversity.

\section{Management solutions}

A clear policy on the introduction of non-native species is needed as aquaculture expands, especially in developing countries. The policy must be clearly made based on the principle that all species are considered potentially harmful and therefore forbidden for introduction unless risk of invasiveness is acceptably low. The ICES Code of Practice on the Introductions and Transfers of Marine Organisms recommends effective procedures and practices to diminish potential risks. The most up-to-date version of this Code, published in 2005, covers all concerns expressed in former versions and follows the precautionary approach adopted from the FAO principles with the goal of reducing the spread of exotic species (ICES 2005). The ICES Code has become a well-recognized instrument, and its essential components have been widely applied to the evaluation of species introductions.

Based on ICES Code, essential components for a sound management programme include the following:

1 Using multiple discipline procedures and the state-ofthe-art technologies for scientific risk assessment and strictly applying a well-evaluated programme to every species proposed for introduction; this is the first priority to stop introductions of harmful species into local environments. Risk assessment relies on scientific methodologies to support decision-making. Methodology successfully developed for the Weed Risk Assessment (WRA, Pheloung et al. 1999) provides a good model to follow-up for the risk assessment of the introduction non-native aquatic species. Indeed, models and tools focusing on different taxonomic groups, such as Freshwater Fish Invasiveness Scoring Kit (FISK) and Marine Invertebrate Invasiveness Scoring Kit (MI-ISK), have been successfully developed based on WRA, and all these tools are made freely available at Centre for Environment, Fisheries \& Aquaculture Science (Cefas) website (http://www.cefas.co.uk/projects/risks-and-impacts-ofnon-native-species/decision-support-tools.aspx). Such tools and models can be adopted, modified and evaluated under various circumstances, such as characteristics 
of different species and different condition of water bodies.

2 Developing new cost-effective tools (such as those based on remote sensing and global positioning system technologies) to monitor introduced species in order to rapidly respond to newly emerged negative effects; this serves as a supplement of recommendation (1) to response to problems caused by those not blocked by the procedure of risk assessment. Indeed, remote-sensing and global-positioning system technologies have been successfully used for detecting and mapping of invasive species, including aquatic invasive species (e.g. MaheuGirouxa \& de Blois 2005). These provide good successful examples to follow-up for other species, although technical questions remain to be solved for wide application.

3 Establishing a legal authority specifically to perform comprehensive risk assessment and to monitor introduced species, especially those having high probabilities to escape, or to be released and discarded into local water bodies. In addition, such a legal authority should be responsible for providing research-based strategic management advice, such as (i) scientifically assessing culture methods (e.g. open versus enclosed) based on biological characteristics of transferred species and environmental conditions of different water bodies (e.g. coastal region, inland lakes, etc.); (ii) establishing a species-specific parameter for the number of escapees, that is a threshold for the establishment of self-sustaining populations and/ or prevention of genetic changes to natural local populations, and subsequently using this parameter to strictly monitor escapees and all release events; (iii) developing sterile stains of transferred species/populations using safe manipulations.

In addition, sound management on non-native species used for aquaculture requires international effort, coordination and collaboration, mainly because some countries have less strict or no regulations on the introduction and use of non-native species. Negative impacts occur in such countries might spread larger areas, finally affecting neighbouring countries. The hazardous Substances and New Organisms Act (1996) implemented in New Zealand provides a common model that other countries could follow. Under this act, importers of non-native species must apply to an independent regulatory authority accountable to the Environment Ministry and Parliament for public approval.

\section{Fellow travellers, accidental introductions}

\section{Background}

Fellow travellers, or hitchhiking species, refer to species that inadvertently accompany the shipment of the species intended for introduction/transfer. Many countries have a long history of importing species for aquaculture and live aquatic products from regional, national and international sources (De Silva et al. 2009; Peeler et al. 2011; De Silva 2012). Fellow travellers, attaching to the surface or inside of the body (e.g. gut, lung and mussel) of these desired species, are introduced into local environments, where they may become invasive and cause huge economic and environmental damages. For example, the European green crab (Carcinus maenus), a voracious predator and aggressive colonizer, is believed to have been introduced to the U.S. west coast in packing materials (seaweeds) of live food fish from the east coast (Yamada \& Gillespie 2008). This crab species has had a strong influence through predation and aggression on biodiversity in invaded ranges (Grosholz \& Ruiz 1995; Jamieson et al. 1998).

\section{Fellow travellers in China}

Despite the fact that micro-organism may be the major group of fellow travellers, we could not make a list in this review, mainly due to difficulties to track origins and poor historical records worldwide. Besides pathogens, a total of three species have clear records as fellow travellers (Table 1), two of which belong to brown algae (Costaria costata, Desmarestia ligulata), and the remaining one is red algae (Trichogloea lubrica; Table 1). All these three species were unintentionally transferred into China along with the introduction of Undaria pinnatifida from Japan (see Table 1 and references therein). It should be noted that the number of fellow travellers can be much larger than what we have known so far, because many fellow travellers remain inconspicuous at subthreshold densities.

\section{Risks}

One of the known examples in China is Desmarestia ligula$t a$, which has become a harmful species in northern China after the introduction along with an aquaculture species Undaria pinnatifida. The length of this species usually reaches $1 \mathrm{~m}$ in China, which is much longer than 30$50 \mathrm{~cm}$ in its native ranges (Liu et al. 2007a). This brown algae release sulphuric acid after death, which can highly increase acidity of sea water. It is well known that ocean acidification has significantly negative impacts on marine ecosystems (see review by Fabry et al. 2008). An outbreak of this species not only can influence local water bodies in China, but also might threaten neighbouring areas after acid is advected and spread by marine currents in 'open' oceans.

\section{Management solutions}

Fast and correct identification of fellow travellers before introduction represents the first and also most important 
step for the prevention of introduction of undesired harmful species. For large fellow travellers, especially those attached on body surface, identification might not be difficult, because large organisms could be easily detected by eye inspection and then eliminated. However, for small organisms such as micro-organisms and those at particular life stages such as eggs and immature individuals, huge challenges remain for fast and correct identification, not only because it poses immense technical difficulties to identify numerous extremely small organisms, but also a large number of micro-organisms often are unidentified hazards (e.g. Whittington \& Chong 2007; Peeler et al. 2011). Unfortunately, currently applied risk assessment usually does not account for unidentified hazards.

There is little double that so far routine quarantine inspection has been the major method for the prevention of introduction of fellow travellers. Besides routine quarantine inspections and exams, several more recommendations can reduce/eliminate risks caused by fellow travellers: (i) introduction of fertilized eggs, instead of adults, should be encouraged to reduce the number of potential fellow travellers; (ii) it is essential to develop high-throughput and effective inspection tools, especially genetic tools based on newly emerged technologies, such as gene probe, microarray, and highly sensitive tools such as 454 pyrosequencing to effectively detect small organisms and low-density populations (Zhan et al. 2013). Indeed, some of these DNAbased methods have been available, pending only the initiative and investment of time and money to tailor tools to specific tasks (See reviews by Darling \& Blum 2007; Darling \& Mahon 2011). In addition, it should be noted that the impending benefits of DNA/RNA-based methods are vast, and worthy of continued effort and investment (Darling \& Blum 2007; Darling \& Mahon 2011).

\section{Artificial hybridization}

\section{Background}

Intra- and inter-specific hybridizations are widely employed in breeding programmes to improve economic properties of aquaculture species, that is, to obtain hybrid vigour or positive heterosis such as growth rate, disease resistance, harvestability and environmental tolerance (Bartley et al. 2001; Hulata 2001). Hybridization possesses many obvious advantages including simplicity of operation, time-saving, and immediate and significant improvement on performance of desired traits (Hulata 2001). Successfully created hybrids constitute a significant proportion of aquaculture production in several countries, such as hybrid striped bass (Morone chrysops $\times$ M. saxatilis) in the USA (Carlberg et al. 2000), hybrid catfish (Clarias gariepinus $\times$ C. macrocephalus) in Thailand (De Silva et al. 2006), and hybrid tilapia (Oreochromis niloticus $\times$ O. aureus) in Israel (Milstein et al. 2001). Owing to these advantages, a large proportion of introduced non-native species is subjected to hybridization practice (see reviews by Bartley et al. 2001; Hulata 2001; Lou \& Li 2006).

\section{Hybridization practice in China}

Hybridization is one of the most common practices in various breeding programmes in China. For intra-specific hybridization, it is common that different geographical populations of a species are introduced into local places where this species naturally occurs. One of the well-known examples is the introduction of Japanese stocks of the Pacific abalone (Haliotis discus hannai) into northern China to resolve the high-mortality problem $(>90 \%)$ caused by diseases in 1994 (Zhang et al. 2004). The hybrids between Chinese and Japanese stocks, which highly improved survival rate (approximately 100\%) and growth rate (approximately 30\%), saved the abalone industry in China (Guo 2009).

For inter-specific hybridization, large-scale trials have been conducted both between native species and nonnative species, and between two non-native species (Table 2). So far, at least $43(24 \%)$ non-native species introduced internationally have been successfully subjected for inter-specific hybridization, yielding at least 63 successful crosses in echinoderms ( 1 cross), mollusks ( 14 crosses), algae (2 crosses) and fish (46 crosses; Table 2). Among these successful crosses, one of the successful examples is hybridization between two non-native species of sea kelps, Laminaria japonica and L. logissima, which were introduced from Japan in 1990s. Based on these two non-native species, more than ten varieties have been created and proven as new varieties with improved economic traits by the National Appraisal Committee of Aquatic Protospecies and Improved Varieties. The Dongfang No.2 (L. longissima $q \times$ L. japonica ${ }^{\text {I) }}$ ) variety improved yield more than $25 \%$ when subjected to large-scale cultivation at different locations (Li et al. 2007b). Now, almost all farmed kelps in China are hybrids.

\section{Risks}

Risks caused by hybrids are mainly genetic pollution (e.g. loss of genetic variation, breakdown of population structure) and species extinction (Huxel 1999; Bartley et al. 2001; Hails \& Morley 2005). The observed diversity and distributions of species are formed by millions of years of evolution. Geographical isolation prevents hybridization and introgression, and species or local populations have been well adapted to local environmental conditions. Aquaculture and related activities 
bring species into contact with their relatives from which these species have been historically isolated, and then further seek possible ways to produce hybrids with positive heterosis. In the absence of hybridization, invaders might be quickly eliminated due to low population density (i.e. Allee or stochastic effects). However, in the presence of hybridization, especially human-mediated hybridization aiming to produce vigourous offspring, non-native genetic materials could rapidly introgress into native gene pools, leading to genetic pollution to local populations and/or replacement of local gene pools. Using mathematical simulations, Huxel (1999) found that displacement of native gene pools could occur very rapidly: less than five generations. Indeed, quick replacement of local gene pools caused by both intra- and inter-specific hybrids has been observed in aquaculture species in China. The Pacific abalone (Haliotis discus hannai) in northern China and carps (genus Cyprinus) in Yunnan province represent good examples for intra- and inter-specific hybrids, respectively. As mentioned previously, hybrids between Chinese and Japanese stocks of the Pacific abalone successfully saved abalone aquaculture industry in the late 1990s in China; however, after several generations farming, $84.1 \%$ of individuals collected from the wild in northern China was identified as hybrids based on molecular markers and corresponding analyses (Wang 2011). Similarly, almost all carps from Lake Xingyun in Yunnan province are inter-specific hybrids, as revealed by both morphological and genetic surveys (Yang et al. 2011). 'Pure'native species do not exist in the wild, that is, species extinction genetically, the worst consequence caused by aquaculture-mediated hybridization. This type of extinction, which is different from 'traditional extinction' (i.e. permanent disappearance of a species), is largely 'invisible' to the human eye and cannot be detected without detailed investigations based on molecular analyses, leading to difficulties to generate an understanding in the public. Owing to a high rate of human-mediated introductions and hybridizations, Huxel (1999) suggested that hybridization alone may become a major cause for species extinction.

\section{Management solutions}

Although empirical studies have shown that some aquaculture-mediated hybrids are threatening local environments and biodiversity, there is still a lack of comprehensive programmes/systems for risk assessment and sound management of farmed hybrids. Several recommendations should be considered before hybrids are practically adopted and widely farmed. (i) Risk assessment, especially probabilities to breed with parental species and relatives in local sur- rounding environments, must be carried out, and the results are used to develop species-specific (e.g. based on unique biological, genetic, physiological characteristics of each hybrid and parental species) and case-specific (e.g. intra- or inter-specific hybridization) performance standards. Although genetically modified organisms (GMOs) are defined by the international community and national governments as organisms created by recombinant DNA technologies, indeed, inter-specific hybridization represents a genetic modification wherein genetic materials from different species are combined in a single species (see review by Bartley et al. 2001 and references therein). The debate on whether or not inter-specific hybrids are GMOs is beyond the scope of this review, but risks caused by interspecific hybrids may be as high as GMOs (Bartley et al. 2001). Consequently, risk assessment programmes for GMOs (e.g. Hill 2005) should be also applied to interspecific hybrids, even to intra-specific hybrids, to approve whether or not these hybrids are environmentally safe enough to be widely farmed in aquaculture. (ii) Proper management of hybridization depends on knowledge of basic background of crossing, such as biological and genetic characteristics of parental species and resulting offspring hybrids, mechanisms of positive heterosis, genotype $\times$ environment interactions, etc. Consequently, intensive research should be performed to clarify these fundamental questions. According to the information obtained from these two recommendations, optimized management measures including culture method, facility design and operation management of the whole grow-out procedure should be advised and strictly followed by aquaculture managers. (iii) An oversight authority should set up surveillance programmes to monitor hybrids and launch quick response programmes for newly emerged negative effects.

\section{Mass release of non-native species for ranching}

\section{Background}

Mass release for ranching is a form of extensive aquaculture. Ranching refers to the release of cultured juveniles into unenclosed environments for harvest at a larger size in 'put, grow and take' operations (Bell et al. 2008). Now large-scale mass release of non-native for ranching has been performed for many aquaculture species in many countries (Shelton \& Rothbard 2006). For example, approximately one-third of the capture harvest in the Caspian Sea was derived from stocked fish (Shelton \& Rothbard 2006). Such aquaculture also supports important industries. For example, the caviar industry in the Black and Caspian Seas was maintained for decades by ranching transplanted sturgeon (McNeil 1979). Although mass release for ranching has been proven to have immediate improvement on 
aquaculture production, adverse effects on local environments and native biodiversity are largely neglected in research and policy (Laikre et al. 2010).

\section{Mass release of non-native species for ranching in China}

Since the 1980s, large-scale release is intentionally performed in almost all major marine and freshwater water bodies in China (Li 2011; Tao \& Wang 2011). The number of both species and released individuals increased rapidly in the past decade. Nationwide, the total number of released individuals increased from 8.9 billion in 2005 to 19.46 billion in 2007, while the value increased from 1.29 to 2.64 billion Chinese Yuan (Li 2011). Based on the National General Plan of Mass Release and Stock Enhancement for Aquatic Organisms (2011-2015), more than 34 billion individuals derived from 167 species are planned to be released into 356 water bodies in 2015. Species used for mass release for ranching in China are of three categories: (i) highly valued aquaculture species, including both native and non-native, of which native ones are the most commonly used in China; (ii) rare and endangered species; (iii) local-endemic species. Despite that the number of species and release scale for non-native species are not as large as those for native species, non-native species, which cover all major aquaculture species categories, have been successfully released for ranching, for example, mollusks such as the Japanese scallop Patinopecten yessoensis, echinoderms such as Japanese sea urchin Strongylocentrotus intermedius, fish such as turbot Psetta maxima, and crustaceans such as black tiger prawn Penaeus monodon and white-leg shrimp Penaeus vannamei.

\section{Risks}

High debate on the merits of large-scale release for ranching increases as the interest of such performance grows in aquaculture (see review by Mustafa 2003). Mass release poses the highest risk for the establishment of populations, mainly owing to a large number of individuals involved and direct release into suitable habitats. Sometimes establishment of populations in the wild may be beneficial to aquaculture; however, once non-native species become established, it is very difficult to control them (see review by Tyus \& Saunders 2000). Established non-native species may become harmful after successfully localized. One representative example in China is the Japanese sea urchin Strongylocentrotus intermedius (Liu et al. 2007a). The established sea urchin populations have threatened local environments and biodiversity, such as destroying seaweed bed and aquaculture facilities, and competing with native species for food and space (Liu et al. 2007a).

\section{Management solutions}

Although mass release of aquaculture species in many countries is partially organized and/or supervised by local or central/federal governments, unfortunately scientific assessment was seldom employed to direct such large-scale releases. Assessment of risk-benefit trade-offs prior to mass release has proven to be most effective way for decisionmaking (Waples \& Drake 2004; Barbour et al. 2008). Studies have indicated that taxa-specific risk-benefit assessment protocols are needed (Waples \& Drake 2004; Barbour et al. 2008). To make effective taxa-specific assessment protocol, research gaps should be filled for species proposed to release, such as what is the observed and expected genetic structure of local populations before and after mass release respectively, how are individuals chosen to minimize genetic change to local populations, and what are biological and environmental consequences after release and how are these consequences properly assessed. All obtained information, including that derived from recommendations for risk assessment and management for each category of species, risk-benefit assessment and research results should be systemically combined and implemented into monitoring programmes. Finally, monitoring programmes need to be linked with management policy to point out outcomes from both mass release and associated monitoring, and management solutions/actions for each outcome.

\section{Conclusions}

Our dependence on non-native species for aquaculture likely becomes greater in the future as it supports increasing demands in aquatic food markets. It is therefore expected that the introduction and/or use of non-native species is more frequent and a common practice in aquaculture. For a practical and realistic perspective, sound management, coupled with good knowledge of possible risks and well prepared solutions for such negative effects, is the way for sustainable development of aquaculture. However, the aquaculture industry must now face the fact that accelerating introduction and/or use of non-native species for aquaculture remain unthoroughly unregulated, especially in developing countries, leading to high risks to ecosystems, economies, and even public health of inhabitants. Recent research adds increasing evidence on negative effects, threats and risks, which has fed back to affect sustainable development of aquaculture. In this review, we discuss observed and potential risks associated with unregulated introduction and irresponsible use of non-native species and recommend solutions for management based on highrisk aquaculture activities and related events employed in the past several decades. 
The lack of risk assessment and sound management for non-native species is particularly true for the sustainable development of aquaculture, although risks and negative effects have been recognized and repeatedly stressed in literature in the past decades. Lessons from known disasters caused by non-native species are slowly learned compared with outbreak scale and spread speed of disasters. Numerous reasons are responsible for such slow pace, and the most important one is that short-term benefit is concentrated and long-term development is highly neglected. In addition, the aquaculture industry is the beneficiary of introductions of non-native species, but aquaculture industry is not made to pay the costs of environment damage once non-native species become invasive.

We stress that there is an extremely urgent need to consider risk assessment and sound management for the introduction and use of non-native species as aquaculture fast expands. Without proper management, negative effects can go extremely high degrees and large geographic scales, and in return, will certainly affect the sustainable development of aquaculture, and even lead to severe disasters to aquaculture. Meanwhile, we also suggest that policies should be put in place to make aquaculture industry pay for environmental damage. Finally, we call for effort and collaboration of researchers from academia, government and industry for responsible introduction and use of non-native species.

\section{Acknowledgement}

This study was supported by National Natural Science Foundation of China (No. 31272665) and "100-Talent Program" of the Chinese Academy of Sciences to A.Z.

\section{References}

Ba J, Chen D (2012) Invasive fishes in Three Gorges Reservoir area and preliminary study on effects of fish invasion owing to impoundment. Journal of Lake Sciences 24: 185-189 (in Chinese with English abstract).

Barbour RC, Crawford AC, Henson M, Lee DJ, Potts BM, Shepherd M (2008) The risk of pollen-mediated gene flow from exotic Corymbia plantations into native Corymbia populations in Australia. Forest Ecology and Management 256: 1-19.

Bartley DM, Rana K, Immink AJ (2001) The use of inter-specific hybrids in aquaculture and fisheries. Reviews in Fish Biology and Fisheries 10: 325-337.

Bartley DM, Bhujel RC, Funge-Smith S, Olin PG, Phillips MJ (comps./eds.) (2005) International mechanisms for the control and responsible use of alien species in aquatic ecosystems. Report of an Ad Hoc Expert Consultation. Xishuangbanna, People's Republic of China, 27-30 August 2003. Rome, FAO. $195 \mathrm{p}$.
Bell JD, Leber KM, Blankenship L, Loneragan NR, Masuda R (2008) A new era for restocking, stock enhancement and sea ranching of coastal fisheries resources. Reviews in Fisheries Science 16: 1-9.

Bian Y, Huang R, Ma S (2010) Technologies for introduction and breeding of the Yellow River catfish Silurus Lanzhouensis. Scientific Fish Farming 9: 8-10 (in Chinese).

Carlberg JM, van Olst JC, Massingill MJ (2000) Hybrid striped bass: an important fish in US aquaculture. Aquaculture $\mathbf{2 6}$ 26-38.

Chang Y, Wang Z, Song J, Su Y, Wang J (2000) Cross breeding between four species of sea urchin, feasibility and early development of F1 offspring. Journal of Fisheries of China 24: 211216 (in Chinese with English abstract).

Chen W (1997) Report on introduction and culture of Macrobrachium nipponense in northern alpine regions of China. Heilongjiang Fisheries 3: 19-20 (in Chinese).

Chen D (2000) Successful artificial breeding of inter-specific hybrid (Carassius auratus cuvieri $\mathrm{x}$ Cyprinus carpio var. singuonensis). Chinese Journal of Zoology 35: 60 (in Chinese).

Chen F (2007) Artificial breeding technology for Arca inflate in impounded sea water in South China. Practical technology in rural areas in Guangdong Province 9: 37-38 (in Chinese).

Chen J, Su R (2006) Studies on the crossbreeding of sunfish. Reservoir Fisheries 26: 38-39 (in Chinese with English abstract).

Chen S, Ye W (1992) Preliminary studies on introduced sunfishes in China. Chinese Journal of Zoology 27: 12-16 (in Chinese).

Chen S, Ye W (1994) Preliminary studies on introduced tilapia in China. Chinese Journal of Zoology 29: 18-23 (in Chinese).

Chen Y, Yang J, Li Z (1998) The diversity and present status of fishes in Yunnan Province. Chinese Biodiversity 6: 272-277 (in Chinese with English abstract).

Chen J, Shen G, Meng S, Qu J (2010) Investigation and study on the aquaculture alien species in the lower reaches of Yangtze River. Chinese Agricultural Science Bulletin 26: 315-319 (in Chinese with English abstract).

Chi X, Jia Z, Li C, Shi L (2010) Analysis of genetic structure in obverse and inverse cross of purse red carp and German mirror carp by microsatellite markers. Journal of Dalian Ocean University 25: 450-455 (in Chinese with English abstract).

China Fisheries Yearbook (2012). China Agriculture Press, Beijing, China, pp. 108.

Darling JA, Blum MJ (2007) DNA-based methods for monitoring invasive species: a review and prospectus. Biological Invasions 9: 751-765.

Darling JA, Mahon AR (2011) From molecules to management: adopting DNA-based methods for monitoring biological invasions in aquatic environments. Environmental Research 111: 978-988.

De Silva SS (2012) Aquaculture: a newly emergent food production sector-and perspectives of its impacts on biodiversity and conservation. Biodiversity Conservation 21: 3187-3220.

De Silva SS, Nguyen TTT, Abery NW, Amarasinghe US (2006) An evaluation of the role and impacts of alien finfish in Asian inland aquaculture. Aquaculture Research 37: 1-17. 
De Silva SS, Nguyen TTT, Turchini GM, Amarasinghe US, Abery NW (2009) Alien species in aquaculture and biodiversity: a paradox in food production. Ambio 38: 24-28.

Ding F, Yang M, Dai X, Zang W (2012) Morphological characteristics in hybridization of yellow perch (Perca flavescens) 우 and Baklhash perch (Perca schrenki Kessler) $\hat{\sigma}$ and artificial rearing techniques. Journal of Aquaculture 33: 8-11 (in Chinese with English abstract).

Dong Z, Xia D, Wu T, Tang H, Xu P (1999) RAPD analysis of heterosis between Xingguo red carp and scattered mirror carp. Journal of Shanghai Fisheries University 8: 31-36 (in Chinese with English abstract).

Doupé RG, Lymbery AJ (2000) Managing translocations of aquatic species. Aquaculture Research 31: 151-156.

Fabry VJ, Seibel BA, Feely RA, Orr JC (2008) Impacts of ocean acidification on marine fauna and ecosystem processes. ICES Journal of Marine Science 65: 414-432.

Fan F (2012) Studies on introduction of Haliotis fulgens and interspecific hybridization with Haliotis discus hannai. Dissertation from Xiamen University, Xiamen, Fujian, China. (in Chinese with English abstract).

Fan H, Lin Y, Zhong Q, Liao B, Zhuo Y, Xin Z (2008) Studies on culture biology characteristics of Anguilla mossambica Peters. Journal of Fujian Fisheries 4: 7-12 (in Chinese with English abstract).

Fan X, Wang Q, Qi X, Luo J, Wang X, Yin S et al. (2009) Studies on genetic relationship between Oxyeleotris marmoratus, Oxyeleotris lineolatus and their first filial generation. Marine Fisheries 31: 128-133.

Fan W, Liu H, Zhao W, Zhang F (2011) Research of morphological characteristics and growth comparison of Fugu flavidus, Fugu rubripes and the hybridization (Fugu flavidus $+\times$ Fugu rubripes $\sigma^{\top}$ ) in early growth stages. Journal of Fisheries of China 35: 1065-1071 (in Chinese with English abstract).

Fang Z, Wang Y, Dan X (2002) Aquaculture technology for Rana tigrina. Inland Aquatic Product 27: 18-19 (in Chinese with English abstract).

Fei J, Tang T, Shao X (2011) Fishery resources and developmental patterns of fishery in Erhai Lake. Wetland Science 9: 277283 (in Chinese with English abstract).

Food and Agriculture Organization of the United Nations (FAO) (2012) The State of World Fisheries and Aquaculture. Fisheries and Aquaculture Department, Rome, Italy, pp. 147.

Gao L, Chen L, Song B, Zhao X, Chen Y (2006) Effect of starvation on digestive system development of hybrid sturgeon (Huso huso $+\times$ Acipenser baeri $\stackrel{\jmath}{\text { ) }}$ ) larvae. Journal of Shanghai Fisheries University 15: 442-447 (in Chinese with English abstract).

Ge H, Jia Z, Li C, Bai Y, Wu Y, Shi L (2012) Parentage identification of Heilongjiang wild carp and German mirror carp cross combinations on microsatellite DNA markers. Journal of Shanghai Ocean University 21: 489-494 (in Chinese with English abstract).

Gong M (2009) Preliminary study on crossbreeding of male Paralichthys dentatus and female Paralichthys Lethostigma.
Journal of Fujian Fisheries 1: 89-92 (in Chinese with English abstract).

Gozlan RE (2008) Introduction of non-native freshwater fish: is it all bad? Fish and Fisheries 9: 106-115.

Grosholz ED, Ruiz GM (1995) Spread and potential impact of the recently introduced European green crab Carcinus maenas in central California. Marine Biology 122: 239-247.

Guan J, Liu X, Lan C, Cai W, Xu Y, Ma S (2007) Effects of temperature and salinity on embryo development and larva survival in crossbreed F1 of Paralichthys olivaceus (q) $\times$ Paralichthys dentatus ( $\widehat{\jmath})$. Marine Fisheries Research 28: 31-37 (in Chinese with English abstract).

Guo Q (2005) Progress and perspectives of whitefish aquaculture in China. Reservoir Fisheries 25: 43-46 (in Chinese).

Guo X (2009) Use and exchange of genetic resources in molluscan aquaculture. Reviews in Aquaculture 1: 251-259.

Hails RS, Morley K (2005) Genes invading new populations: a risk assessment perspective. Trends in Ecology and Evolution 20: $245-252$.

Hao L, Shi H, Wang N, Chen K (2005) Present status and ecological harming of alien marine organism invasion. Advances in Marine Science 23: 121-126 (in Chinese with English abstract).

Harasewych MG, Moretzsohn F (2010) The Book of Shells. A Life-Size Guide to Identifying and Classifying Six Hundred Seashells. The University of Chicago Press, Chicago, IL.

He Y, Zhang J, Wang W, Zhang S (1995) Studies on breeding of Xinhuai hybrid carp (Carassius auratus cuvieri $9 \times$ Cyprinus carpio var. specularis $\widehat{\jmath})$. Journal of Shanghai Fisheries University 4: 76-78 (in Chinese with English abstract).

He Y, Yang T, Liu J, Yang Z (2010) The investigation of the fish current resources in Erhai Lake. Journal of Chuxiong Normal University 25: 53-58 (in Chinese with English abstract).

Hill RA (2005) Conceptualizing risk assessment methodology for genetically modified organisms. Environmental Biosafety Research 4: 67-70.

Hou X (1998) On biological characteristics of significant economical abalones in the world. Shandong Fisheries 15: 20-22 (in Chinese).

Hu H, Zhu H, Ma G, Guo H, Yao Z, Li L (2008) Comparison of biological characteritics and growth of six sturgeon hybrids. Abstract Collection of 2008 Annual Conference of the Society of Fisheries of China, p 48. (in Chinese).

Hulata G (2001) Genetic manipulations in aquaculture: a review of stock improvement by classical and modern technologies. Genetica 111: 155-173.

Huxel GR (1999) Rapid displacement of native species by invasive species: effects of hybridization. Biological Conservation 89: 143-152.

ICES (2005) ICES Code of Practice on the Introductions and Transfers of Marine Organisms 2005. ICES, Copenhagen, Denmark, 30p.

Jamieson GS, Grosholz ED, Armstrong DA, Elner RW (1998) Potential ecological implications from the introduction of the European green crab, Carcinus maenas (Linneaus), to British 
Columbia, Canada, and Washington, USA. Journal of Natural History 32: 1587-1598.

Jeschke JM, Strayer DL (2005) Invasion success of vertebrates in Europe and North America. Proceedings of the National Academy of Sciences of the United States of America 102: 71987202.

Jin W, Zhu Z, Wang C, Yu Y, Wang S, Zhao Y (2003) Hybridization between Cyprinus carpio var. specularis $($ $($ ) $\times$ Megalobrama amblycephala $(\hat{\delta})$ and morphological characteristics of F1 hybrid. Freshwater Fisheries 33: 16-18 (in Chinese).

Karjan A, Su D, Yang Y, Ye S, Huderat (2006) The current situation and the countermeasures of protection and development of fish resources in Ulungur Lake. Journal of Shanghai Fisheries University 15: 308-314 (in Chinese with English abstract).

Kong X, Xiong Y (2002) Aquaculture trial on introduced Pseudosciaena crocea in south Shandong Province. Shandong Fisheries 19: 23-24 (in Chinese).

Laikre L, Schwartz MK, Waples RS, Ryman N, The GeM Working Group (2010) Compromising genetic diversity in the wild: unmonitored large-scale release of plants and animals. Trends in Ecology and Evolution 25: 520-529.

Li X (1992) New valued fish species - Channa striatus. Scientific Fish Farming 2: 22 (in Chinese).

Li L (2009) Biological Studies on Breeding of Two Color Variants of Sea Cucumbers. Dissertation from the Ocean University of China, Qingdao, China.

Li X (2011) Releasing proliferation impact assessment of Chinese shrimp in the southern Shandong Peninsula. Dissertation from the Chinese Academy of Agricultural Sciences, Beijing, China. (in Chinese with English abstract).

Li C, Xie F (2004) Invasion of bullfrog (Rana catesbeiana Show) in China and its management strategies. Chinese Journal of Applied Environmental Biology 20: 95-98 (in Chinese with English abstract).

Li S, Zheng B, Fei X (1992) Northward transplant of Porphyra haitanensis in China. Oceanologia et Limnologia Sinica 23: 297-301 (in Chinese with English abstact).

Li G, Fang Q, Tang D (2002) Aquaculture technology of Annamemys annamensis. Reservoir Fisheries 22: 19. (in Chinese).

Li S, Xu X, Du L, Yin X, Meng X, Xie J (2005) Investigation and analysis of alien invasions in Chinese farming industry. Chinese Agricultural Science Bulletin 21: 156-159 (in Chinese with English abstract).

Li J, Dong Z, Li Y, Wang C (2007a) Alien Aquatic Plants and Animals in China. Shanghai Scientific and Technical Publishers, Shanghai, China (in Chinese).

Li X, Cong Y, Yang G, Shi Y, Qu S, Li Z et al. (2007b) Trait evaluation and trial cultivation of Dongfang No. 2, the hybrid of a male gametophyte clone of Laminaria longissima (Laminariales, Phaeophyta) and a female one of L. japonica. Journal of Applied Phycology 19: 139-151.

Li F, Zhang J, Yuan Y, Feng H, Zhang J, Yang X (2008) Present situation and problems on fish introduction in Yellow River system. Journal of Anhui Agricultural Sciences 36: 1502415026 (in Chinese with English abstact).
Liang Y, Wang B (2001) Alien marine species and their impacts in China. Biodiversity Science 9: 458-465 (in Chinese with English abstract).

Lin W (2010) Healthy farming technique on floating rafts for Haliotis discus hannai. Ocean and Fishery 7: 37-38 (in Chinese).

Lin Z, Zhou T (2001) Artificial breeding of the alligator snapping turtle Chelydra serpentina. Freshwater Fisheries 31: 9-11 (in Chinese).

Liu H (2004) The advancement of biological research in amphibian culture in China. Journal of Dalian Fisheries University 19: 120-125 (in Chinese with English abstract).

Liu X (2005) Genetic diversity of Ruditapes philippinarum and phylogeny of the genus Ruditapes. Dissertation from the Ocean University of China, Qingdao, China. (in Chinese with English abstract).

Liu R, Wang H, Chen J (1985) Investigation on sexual difference composition of serum protein of two tilapia and their hybrid. Journal of Fisheries of China 9: 265-273 (in Chinese with English abstract).

Liu M, Shen J, Wang Q, Zhang T (1993) Major economic traits and genetic characteristics of Songpu carp (Cyprinus carpio var. mirror $\times$ C. carpio var. specularis). Journal of Fisheries 1: 17-20 (in Chinese).

Liu Y, Yang J, Zhang J (1995) Introduction and artificial culture of Scylla serrata. Hebei Fisheries 81: 11-12 (in Chinese).

Liu X, Lei L, Liu Z, Liu X (1999) Mass culture of Nannochloropsis oculata and the rotifer Branchionus plicatilis as living diets for red sea bream. Marine Sciences 24: 47-51 (in Chinese with English abstract).

Liu S, Wang F, Yang M, Wang J, Yang J, Huang Z (2003) Investigation and study on the alien species in aquaculture in Shandong Province. Marine Fisheries Research 24: 66-71 (in Chinese with English abstract).

Liu F, Liao J, Zheng Z, Wang Y (2007a) Present situation, hazards and prevention and control measures of marine invasive alien species to China. Coastal Engineering 26: 49-56 (in Chinese with English abstract).

Liu J, Li W, Shi Z, Wang Y, Chen Y (2007b) A preliminary study on growth performance of juvenile hybrid Kaluga (Huso dauricus) $\times$ Siberian sturgeon (Acipenser baerii) under artificial farming conditions. Freshwater Fisheries 38: 63-67 (in Chinese with English abstract).

Liu X, Liu X, Lian J, Wang Y, Zhang F, Yu H et al. (2008) Large scale artificial reproduction and rearing of Sengal sole, Solea senegalensis Kaup. Marine Fisheries Research 29: 10-16 (in Chinese with English abstract).

Lodge DM, Williams S, MacIsaac HJ, Hayes KR, Leung B, Reichard S et al. (2006) Biological invasions: recommendations for U.S. policy and management. Ecological Applications 16: 2035-2054.

Lou Y (2000) Present situation and countermeasure of the study on fish introduction in China. Journal of Fisheries of China 24: 185-192 (in Chinese with English abstract). 
Lou Y, Li X (2006) Distant hybridization of fish and its application in aquaculture in China. Journal of Fishery Sciences of China 13: 151-158 (in Chinese with English abstract).

Lou Y, Shen H, Xu Q (1995) Comparative studies on biochemical compositions in sekum of Gaoyou hybrid crucian carp (Carassius auratus auratus + × Carassius auratus cuvieri $\jmath^{\jmath}$ ) and its parents. Acta Hydrobiologica Sinica 2: 157-163 (in Chinese with English abstract).

Lu J, Wang G (2010) Successful culture of hybrid between Hephaestus fuliginosus and Scortum barcoo. Marine and Fisheries 11: 49-50 (in Chinese).

Maheu-Girouxa M, de Blois S (2005) Mapping the invasive species Phragmites australis in linear wetland corridors. Aquatic Botany 83: 310-320.

Mao Z (1988) Successful introduction and cultivation of Palmaria palmate in Fujian Province. China Fisheries 3: 30 (in Chinese).

McNeil WJ (1979) Review of transplantation and artificial recruitment of anadromous species. In: Pillay TVR, Dill WA (eds) Advances in Aquaculture, pp. 547-554. Fishing News Ltd, Surrey.

Messing RH, Wright MG (2006) Biological control of invasive species: solution or pollution? Frontiers in Ecology and the Environment 4: 132-140.

Milstein A, Avnimelech Y, Zoran M, Joseph D (2001) Growth performance of hybrid bass and hybrid tilapia in conventional and active suspension intensive ponds. The Israeli Journal of Aquaculture-Bamidgeh 53: 147-157.

Mustafa S (2003) Stock enhancement and sea ranching: objectives and potential. Reviews in Fish Biology and Fisheries 13: 141-149.

Naylor RL, Williams SL, Strong DR (2001) Aquaculture - a gateway for exotic species. Science 294: 1655-1656.

O’Dowd DJ, Green PT, Lake PS (2003) Invasional "meltdown" on an oceanic island. Ecology Letters 6: 812-817.

Pang S (2005) Progress in marine biological culture collection centre I: successful introduction of the Atlantic subtidal red alga Palmaria palmate. Marine Sciences 29: 86 (in Chinese with English abstract).

Peeler EJ, Oidtmann BC, Midtlyng PJ, Miossec L, Gozlan RE (2011) Non-native aquatic animals introductions have driven disease emergence in Europe. Biological Invasions 13: 12911303.

Peng C, Wen X, Lin Z, Zhou H, Chen S, Lin G (2007) Response of Gracilaria lemaneiformis to nitrogen and phosphorus eutrophic seawater. Journal of Plant Ecology 31: 505-512 (in Chinese with English abstract).

Pheloung PC, Williams PA, Halloy SR (1999) A weed risk assessment model for use as a biosecurity tool evaluating plant introductions. Journal of Environmental Management 57: 239251.

Qian W, Chen Z (2003) Study on the ecological adaptability of forest frog Rana chensinensis moved to the South. Journal of Economic Animal 7: 25-28 (in Chinese with English abstract).

Qin Y, Li X, Zhou B, Zhou H, Duan J, Chu G (2009) Genetic relationship of Placopecten magellanicus and three scallop spe- cies by AFLP. Journal of Northeast Agricultural University 40: 69-74 (in Chinese with English abstract).

Ren W, Ma R (2001) Progress on aquaculture of sturgeons. Inland Aquatic Product 26: 39-40 (in Chinese).

Ren W, Shao D (2004) Aquaculture of Eriocheir sinensis in large water bodies in western alpine regions of China. Freshwater Aquaculture 3: 38-39 (in Chinese).

Ren H, Lan Z, Xiong Z, Lan D (2012) The impact of different diets on the survival of sturgeon hybrids. Guangdong Feed 3: 26-28 (in Chinese).

Ryman N (ed.) (1981) Fish Gene Pools. Ecological Bulletins 34. Editorial Service, FRN, Stockholm, Sweden.

Shao K, Li X (2000) Seasonal variation of benthic seaweed community in the intertide in Dalian. Journal of Dalian Fisheries University 15: 29-34 (in Chinese with English abstract).

Shelton WL, Rothbard S (2006) Exotic species in global aquaculture - a review. The Israeli Journal of Aquaculture - Bamidgeh 58: 3-28.

Shen Y, He X (1990) Report on movement northward of Pinctada maxima: I introduction, domestication and wintering. Journal of Wuhan University (Natural Science Edition) 2: 123125 (in Chinese with English abstract).

Song B, Lin X, Xu Z (2012) Effects of upstream exercise training on feeding efficiency, growth and nutritional components of juvenile tinfoil barbs (Barbodes schwanenfeldi). Journal of Fisheries of China 36: 106-114 (in Chinese with English abstract).

Su T (2006) Research progress on germplasm resources in Haliotis diversicolor diversicolor and $H$. diversicolor aquatilis. South China Fisheries Science 2: 64-67 (in Chinese with English abstract).

Sun L (2000) Culture technologies and applications of Dunaliella salin. Fisheries Science and Technology Information 27: 120 (in Chinese).

Sun Y, Song W, Zhong Y, Zhang R, Chen R (2000) Phylogenetic study of Artemia from China using RAPD and AFLP markers. Acta Genetica Sinica 27: 210-218 (in Chinese with English abstract).

Sun Z, Song Z, Zheng Z, Liu H, Sun Y (2001) A study on hybridization between Haliotis gigantean and Haliotis discus hannai. Shandong Fisheries 18: 25-27 (in Chinese).

Sun J, Liu C, Wang K, Zhu Y (2009) A comparative trial for raising several species of hybrid sturgeon in reservoir cage. Chinese Journal Fisheries 22: 47-50 (in Chinese with English abstract).

Sun D, Shao M, Ma Y, Song L, Hu J, Zhang Z (2010) Research on species composition and distribution of large-scale fouling organisms on scallop farming cages using test panels. Periodical of Ocean University of China 40: 84-90 (in Chinese with English abstract).

Tang M, Lin Y (1993) Population dynamics of Artemia franciscana in experimental ponds in Tong'an City. Journal of Oceanography in Taiwan Strait 1: 55-60 (in Chinese).

Tang X, Sui Z, Li X, Yang M (2007) Trail of culture of Cynoglossus semilaevis in cement ponds in Hainan Province. Scientific Fish Farming 5: 22-23 (in Chinese). 
Tao L, Wang W (2011) Actuality analysis and strategy on fishery resources proliferation activities in Zhoushan sea area during the "eleventh five-year plan". Journal of Zhejiang Ocean University (Natural Science) 30: 436-442 (in Chinese with English abstract).

Teng S (2009) Hybridization breeding of the Pacific oyster Crassostrea gigas. Dissertation from the Ocean University of China, Qingdao, China.

Tyus HM, Saunders JF III (2000) Nonnative fish control and endangered fish recovery: lessons from the Colorado River. Fisheries 25: 17-24.

Wan J, Wang X, Pan J, Li B, Li Z, Bao Z (2001) RAPD analysis of the genetic change in parent abalone and their hybrids. Journal of Ocean University of China 31: 506-512 (in Chinese with English abstract).

Wang D (1995) The changes of fishes fauna and protections of aboriginal fishes in the Tarim River. Arid Zone Research 12: 54-59 (in Chinese with English abstract).

Wang X (2003) The red swamp crayfish Procambarus clarkia, a harmful alien invasive species. Food and Life 10: 24-25 (in Chinese).

Wang Y (2006) A preliminary study on inter-specific breeding technology between Haliotis discus $\times H$. gigantean. Shandong Fisheries 23: 50-51 (in Chinese).

Wang M (2011) The impacts of hybrids farming on genetic structure of native populations of Pacific abalone and genetic analysis of interspecific introgressive hybridization. Dissertation from the Ocean University of China, Qingdao, China. (in Chinese with English abstract).

Wang R, Fan J (1999) Artificial breeding of red abalone, Haliotis refescens, and cross breeding with Pacific abalone, $H$. discus hannai Ino. Journal of Dalian Fisheries University 14: 64-66 (in Chinese with English abstract).

Wang L, Wang M (2006) Successful introduction of Halocynthia roretzi in Rongcheng City. Hebei Fisheries 148: 62 (in Chinese).

Wang L, Han J, Xu W, Wang X, Dong Y, Zhou Z (2003) The species hybridization between sea urchin Strongylocentrotus nudus and Strongylocentrotus intermedius and the seeding production. Fisheries Science 22: 9-11 (in Chinese with English abstract).

Wang C, Liu B, Li J, Liu S (2009a) A study on inter-specific hybridization between Argopecten purpuratus and A. irradians. Marine Sciences 33: 84-87 (in Chinese).

Wang D, Wu J, Dou Y, Huang C (2009b) Study on fish environmental risk of allopatry introduced in China domestic. Journal of Anhui Agricultural Sciences 37: 8544-8546 (in Chinese with English abstract).

Wang N, Yang G, Peng T, Qu Q, Sun D, Wu W et al. (2010a) Comparison of offspring survival of three kinds of sturgens' purebreds and crossbreds. Journal of Sichuan Agricultural University 28: 507-511 (in Chinese with English abstract).

Wang N, Yang G, Peng T, Sun D, Wang C (2010b) Analysis on muscle nutritive components of three kinds of sturgeons and their Hybrids. Journal of Jilin Agricultural University 32: 53-56 (in Chinese with English abstract).
Wang Z, Jiang Z, Zhang C, Han C, Wang N, Bai X (2010c) Checklist literature study and compilation of bracketed keys for indigenous fishes in Tarim River basin. Progress in Fishery Sciences 31: 15-18 (in Chinese with English abstract).

Wang Z, Liang Z, Peng H, Tong W (2010d) Study on culturing imported species Sparus aurata. Journal of Tropical Oceanography 29: 164-167 (in Chinese with English abstract).

Waples RS, Drake J (2004) Risk/benefit considerations for marine stock enhancement: a Pacific salmon perspective. In: Leber KM, Kitada S, Blankenshipp HL, Svåsand T (eds) Stock Enhancement and Sea Ranching: Developments, Pitfalls and Opportunities, 2nd edn, pp. 260-306. Blackwell, Oxford, UK.

Wei L, Zhou X, Yu G, Geng X (1997) Studies on north moved temperature controlling breeding technique of Pinctada martensii. Journal of Fisheries of China 21: 49-55 (in Chinese with English abstract).

Whittington RJ, Chong R (2007) Global trade in ornamental fish from an Australian perspective: the case for revised import risk analysis and management strategies. Preventive Veterinary Medicine 81: 92-116.

Wu G, Chen K, Luo J, Lin G, Xian Z, Zhong H (1990) Comparative studies on Lactate dehydrogenase isozyme in three species of catfish. Zoological Research 11: 241-247 (in Chinese with English abstract).

Xia D, Cao Y, Yang H, Wu T (1999) The relationships between F1 hybrids from tilapia and their parents and the use of their heterosis. Journal of Fishery Sciences of China 6: 29-32 (in Chinese with English abstract).

Xiong B, Mei X, Dai Z (2008a) Review on introduction of Paddlefish (Polyodon spathula) into China for 20 years. Freshwater Fisheries 38: 70-73 (in Chinese with English abstract).

Xiong F, Li W, Pan J (2008b) Present status of alien fishes and analysis of relative problems in Fuxian Lake in Yunnan Province. Acta Agriculturae Jiangxi 20: 92-94 (in Chinese with English abstract).

Xu G, Li Y, Jia Z, Yang S, Mou Z (2006) Blood indices of rainbow trout(Oncorhynchus mykiss), coho $\operatorname{salmon}(O$. kisutch) and their hybrid. Journal of Dalian Fisheries University 21: 212-218 (in Chinese with English abstract).

Yamada BS, Gillespie GE (2008) Will the European green crab (Carcinus maenas) persist in the Pacific Northwest? ICES Journal of Marine Science 65: 725-729.

Yan X, Zhenyu L, Gregg WP, Dianmo L (2001) Invasive species in China - an overview. Biodiversity and Conservation 10: 1317-1341.

Yan B, Li S, Cai W (2007) Microsatellite analysis of Oreochromis niloticus, Sarotherodon melanotheron and their reciprocal hybrids. Journal of Fisheries of China 31: 411-415 (in Chinese with English abstract).

Yang B (2006) Cage culture technology for hybrid sturgeon species. Scientific Fish Farming 2: 10-11 (in Chinese).

Yang Z, Cai J (2002) Smooth Australian abalone - a study on introduction and farming in China. Scientific Fish Farming 9: 21 (in Chinese). 
Yang S, Lu M, Huang Z, Gao F (2006) Comparison of growthperformance of five hybrid F1 tilapias. Freshwater Fisheries 36: 41-44 (in Chinese with English abstract).

Yang J, Lu F, Zhong Z (2007) Experiment on the culture of Paralichthys olivaceus introduced southward to Guangxi Zhuang Autonomous Region from Shandong Province. Marine Fisheries 29: 186-189 (in Chinese with English abstract).

Yang B, Chen X, Yang J (2011) Non-native carp of the genus Cyprinus in Lake Xingyun, China, as revealed by morphology and mitochondrial DNA analysis. Biological Invasions 13: 105-114.

Yu J, Xia D, Yang H, He Y, Wu T (2003) Morphology of the progenies of Oreochromis aurea $($ 우 $) \times$ Sinipperca chuatai $(\precsim)$. Journal of Fisheries of China 27: 431-435 (in Chinese with English abstract).

Yuan G, Ru H, Liu X (2010) Fish diversity and fishery resources in lakes of Yunnan Plateau during 2007-2008. Journal of Lake Sciences 22: 837-841 (in Chinese with English abstract).

Zeng G (2001) Culture technology of Eucheuma striatum. Journal of Aquaculture 3: 5-7 (in Chinese).

Zhan A, Hulák M, Sylvester F, Huang X, Adebayo AA, Abbott CL et al. (2013) High sensitivity of 454 pyrosequencing for detection of rare species in aquatic communities. Methods in Ecology and Evolution, 4: 558-565.

Zhang J (1989) Crossing trial of Clarias lazera $(q) \times$ C. fuscus (ठ). Guangxi Aquaculture Technology 1: 25-28.

Zhang Y, Yang Z (1997) The latest trends in research and product development of Spirulina. Marine Sciences 5: 68-70 (in Chinese).

Zhang F, He Y, Qi L, Sun L (1997) Studies on the restoration of cultured bay scallop Argopecten Irradians through reintroduction of broodstock. Oceanologia et Limnologia Sinica 28: 146152 (in Chinese with English abstract).

Zhang Z, Fan C, Cao S, You X (1998) Study on the indoor culture and cultivation of Laminaria longissima Mijabe. Journal of Dalian Fisheries University 13: 1-6 (in Chinese with English abstract).

Zhang G, Que H, Liu X, Xu H (2004) Abalone mariculture in China. Journal of Shellfish Research 23: 947-950.

Zhang Q, Tang X, Cong Y, Qu S, Luo S, Yang G (2007) Breeding of an elite Laminaria variety 90-1 through inter-specific gametophyte crossing. Journal of Applied Phycology 19: 303-311.

Zhang Y, Bai Q, Jia Z, Mou Z, Zhao H (2009) Microsatellite analysis of Oncorhynchus mykiss, Oncorhynchus masou masou and their hybrid offspring (Oncorhynchus mykiss $q \times$ Oncorhynchus masou masou $\widehat{\jmath}$ ). Journal of Fisheries of China 33: 188-195 (in Chinese with English abstract).

Zhang X, Sun X, Liang Y, Yang P (2011) Aquaculture technology for Plectropomus leopardus in North China. Scientific Fish Farming 7: 34-35 (in Chinese).

Zhang S, Zhang G, Li L (2012a) Reproductive isolation of interspecific crosses between Argopecten irradians and Argopecten purpuratus. Marine Sciences 36: 9-14 (in Chinese).

Zhang Y, Wang Z, Yan X, Yao T, Yu Z, Huo Z et al. (2012b) Interspecific hybridization between two oysters Crassostrea gigas and C. ariakensis. Journal of Fisheries of China 36: 12151224 (in Chinese with English abstract).

Zhao C, Yao L, Dong C, Ren B, Zhao C (2003) Study on transplant biology of pond smelt Hypomesus transpacificuc nipponesis in Xigou Reservoir. Chinese Journal of Fisheries 16: 44-49 (in Chinese with English abstract).

Zheng G (2009) Duo-culture technology of Kareius bicoloratus and prawn. China Fisheries 2: 43 (in Chinese).

Zhuang Z, Chen S, Liu C, Ma A, Song Z (2009) Technologies for large-scale seedling breeding and healthy aquaculture of Platichthys stellatus. China Science and Technology Achievements 10: 15 (in Chinese).

Zou L, Zhang X (2003) Effects of mutagen MNNG on cell morphological change and growth of marine microalgae Tetraselmis sp. Marine Sciences 27: 47-51 (in Chinese with English abstract). 